\title{
COLLECTIVE BARGAINING AND COMPETITION: THE APPLICATION OF ANTITRUST STANDARDS TO UNION ACTIVITIES
}

\author{
RALPH K. WINTER, JR.*
}

The applicability of the Sherman Act $^{1}$ to union activities has been one of the most disputed legal issues of this century. As late as 1940, for instance, three justices of the United States Supreme Court asserted, in dissent, that a violent strike violated the Sherman Act merely because it prevented the shipment of finished goods in interstate commerce, ${ }^{2}$ while the majority held it a matter for local authorities. ${ }^{3}$ Simultaneously, the Department of Justice was beginning a controversial, and ultimately ill-starred, series of criminal antitrust prosecutions against certain unions. ${ }^{4}$ Even today, 73 years after passage of the Sherman Act and 49 years after the last legislation explicitly directed to the labor-antitrust problem, ${ }^{5}$ the debate goes on. ${ }^{6}$ Whether to apply the antitrust laws to labor, however, has never been a single, well-defined issue. The debate has, at one time or another, touched on almost every fundamental issue of labor policy: the extent of federal responsibility $;^{7}$ the proper role of the executive, judicial, and legislative branches in formulating labor policy ;

1. 26 Stat. 209 (1890), as amended, 15 U.S.C. $\$ \$ 1-7$ (1958).

2. Apex Hosiery Co. v. Leader, 310 U.S. 469, 514 (1940) (dissenting opinion).

3. Id. at 469 .

4. This campaign is described and effectively attacked in Shulman, Labor and the Anti-Trust Lawes, 34 IrL. L. Rev. 769, 779 (1940).

5. Clayton: Act, § 6, 38 Stat. 731 (1914), 15 U.S.C. § 17 (1958); § 20, 38 Stat. 738 (1914), 29 U.S.C. $\$ 52$ (1958).

6. See, e.g., Atr'y Gen. Nat's Coms. Antitrust Rep. 293 (1955) ; Barnes, Goldberg \& Miller, Unions and the Antitrust Laws, 7 LAB. L.J. 133, 178, 186 (1956) ; Bernhardt, The Allen-Bradley Doctrine: An Accommodation of Conflicting Policies, $110 \mathrm{U}$. PA. L. Rev. 1094 (1962) ; Cox, Labor and the Antitrust Lawes-A Preliminary Analysis, $104 \mathrm{U}$. PA. L. REv. 252 (1955).

7. Any application of the Sherman Act to unions necessarily involves federal regulation. In a large sense, judicial use of the anti-trust laws to limit union activity, in conjunction with the constitutional nullification of several state laws designed to benefit labor, see Truax v. Corrigan, 257 U.S. 312 (1921), foreclosed consideration of state responsibility in the formulation of labor policy, for only aroused political forces at the national level could change the existing law.

8. See notes 62-225 infra and accompanying text. Executive involvement at the political level is obvious. But the Sherman Act authorizes the government to bring both civil and criminal proceedings and in a number of cases this power was used to prevent union activity thought to be particularly harmful. E.g., United States v. Brims, 272 U.S. 549 (1926) (hot cargo clauses); Williams v. United States, 295 Fed. 302 (5th Cir. 1924) (putting quicksilver in locomotive engines); United States v. Painters Dist. Council, 44 F.2d 58 (N.D. Ill. 1930), aff'd, 284 U.S. 582 (1931) (make-work practices); United States v. Railway Employees' Dep't, 283 Fed. 479 (N.D. Ill. 1922) (railroad strike) ; United States v. Norris, 255 Fed. 423 (N.D. IIl. 1918) (extortionate picketing). Executive involvement 
the content of national policy toward collective bargaining; the legality of labor's economic weapons $; \theta$ and the permissible objects of union economic force. ${ }^{10}$

It is perhaps surprising, in view of the pervasive regulation of collective bargaining by the National Labor Relations Act ${ }^{11}$ and congressional inaction concerning labor under the Sherman Act, that the debate has not lost contemporary relevance. But it has not, and for two reasons. The first is that the Sherman Act, in the labor context, is a symbol which arouses great emotion, if not passion. That statute, vigorously enforced by extravagant use of the labor injunction, ${ }^{12}$ long served as a principal fount of federal regulation of industrial conflict. Hence, the antitrust laws, along with the injunction, became the focal point of the entire controversy over labor policy ${ }^{13}$ and served as a symbol to

also had a dramatic impact on the course of the law by causing the ostensibly far-reaching decision in United States v. Hutcheson, 312 U.S. 219 (1941). See notes 135-42 infra and accompanying text.

Because the unilluminating language of the Sherman Act provides no guides for regulation of union activity and the anti-trust impact of the Clayton and Norris-LaGuardia Acts was never patently clear, almost every labor anti-trust case raises questions as to the respective responsibilities of the judicial and legislative branches in formulating labor policy. Three cases of great importance in this respect, however, are Loewe v. Lawlor, $20 S$ U.S. 274 (1908) ; Duplex Printing Press Co. v. Deering, 254 U.S. 443 (1921); and United States v. Hutcheson, supra.

9. E.g., Bedford Cut Stone Co. v. Journeymen Stone Cutters' Ass'n, 274 U.S. 37 (1927).

10. E.g., United States v. Painters Dist. Council, 44 F.2d 58 (N.D. I11. 1930), aff'd, 284 U.S. 582 (1931) ; Coronado Coal Co. v. UMW, 268 U.S. 295 (1925).

11. 49 Stat. 449 (1935), as amended, 29 U.S.C. $\$ \$ 151-68$.

12. See generally Frankfurter \& Greene, The Labor Injunction (1930).

13. But in one field of its operations the Sherman law has had clear results. There can be no doubt of its potency as a restraint upon the activities of organized labor. ... But when all discounts are made, it is common ground among students of the Sherman Law, as well as among industrial and labor leaders, that it has been one of the strongest influences counteracting trade unionism in the United States. Yet labor consistently denies that its activities are even subject to the Sherman Law. Though it has been judicially settled since 1908 that labor is amenable to the Sherman Law, the question is not closed for historians and it is wide open in the minds of labor. If moral assent to the authority of a law is of vital importance to the reign of law in a democracy, it can never be too late or too academic to examine the grounds on which rest even so well settled a doctrine as that the Sherman Law governs the activities of labor organizations.

Frankfurter, Foreword to BerMan, LABOR ANd the SHERMan Act at xiv (1930).

The "injunction question" as it exists today is much more extensive than the legal process known as the injunction. In the minds of trade unionists, the "abuse of injunctions" includes the numerous criminal prosecutions growing out of labor disputes-in fact, all of labor's grievances against the law.

Witte, The Government in Labor Disputes at vii (1932).

14. See, e.g., Miller, Unions and the Antitrust Lawe, 7 LAB. L.J. 186 (1956), and Lewis, The Labor Monopoly Problem: A Positive Program, 59 J. PoL. Econ. 277, 278 (1951). 
the partisans of both sides. Indeed, it is no exaggeration to assert that whenever change in the labor laws has been thought desirable, at least outside the area of internal union affairs, someone has suggested widening or narrowing the applicability of the Sherman Act to unions. Neither time nor extensive regulation under the NLRA has diminished the role of the antitrust laws in the debate over labor policy. They have served only to make it more irrational. One of the most popular "anti-union" positions of the day is to advocate elimination, by congressional amendment or judicial reversal, of labor's "exemption" from the Sherman Act. ${ }^{14}$ Predictably, the "pro-union" response is to assert that we must not go back to the "old days" and the decision in Loewe $v$. Lazolor. ${ }^{14 a}$ But these arguments ignore the existing state of the law. ${ }^{15}$ Many of the older cases restricting union activities now have statutory counterparts which achieve, for the most part, the same results. As for labor's "exemption," there is reason to believe it is largely illusory. Nevertheless, the very fact that the Sherman Act, however inaccurately, is such an emotional symbol continues to have an enormous influence on the course of judicial decisions and legislative actions. For that reason, a commentary on labor and antitrust must take the symbolic significance of the Sherman Act into account, even though it cannot be given unqualified respect.

Debate over the applicability of the Sherman Act to labor seems endless for yet another reason. Although the law may severely limit labor's use of certain economic weapons, unions are far more powerful and strategically entrenched today than at the time of Loewe $v$. Lazvlor, and collective bargaining is a significant force shaping the economy. The antitrust laws, on the other hand, play a major role in national economic policy and are designed to regulate the structure and conduct of markets and to promote competition. The relationship of collective bargaining to product competition, therefore, is an issue of great contemporary relevance.

It will be maintained here that collective bargaining based on employee organization along product market ${ }^{15}$ lines creates significant anti-competitive incentives in both labor and management. It may even depend for its very existence, in some instances, upon limiting the competition among employers. This situation, moreover, is aggravated by the failure of the labor laws to be concerned with the purposeful effectuation of national economic policy and their misplaced reliance upon a conflict of interest between labor and management to neutralize the market power created by collective bargaining.

The courts have, for some seventy-odd years, sought to harmonize the conflicting policies of collective bargaining and competition. But the conflict is so irreconcilable that, apart from entirely subordinating one to the other, the regu-

14a. 208 U.S. 274 (1908).

15. The absurdity of most of the debate is effectively exposed in Sovern, Some Ruminations on Labor, the Antitrust Laws and Allen-Bradley, 13 LAB. L.J. 957 (1962). This is also an excellent article, albeit all too brief, for suggesting that Allen-Bradley can easily be read to impair collective bargaining substantially.

15a. Product market as used herein includes markets for both services and commodities provided by firms to customers. 
latory distinctions employed must be largely arbitrary-there are no general principles by which these policies can be harmonized. And since the courts generally must rely on principle in the exercise of the judicial function, their record is not a happy one. The attempt of the courts to accommodate these policies, it will be argued, has merely obscured the nature of the conflict, perverted the judicial process and misdirected attempts by the political process to preserve competitive markets. One purpose of this commentary, therefore, will be to define the appropriate scope of judicial responsibility in this area.

A final purpose will be to suggest directions legislation might take and techniques it might employ toward the end of reconciling collective bargaining and competition. None of these, however, is intended as either a final or intellectually satisfying solution. Such total solutions can be reached only by abandoning one policy for the other, a result not only undesirable but in part unnecessary.

\section{Collective Bargaining and Product Market Competition}

A discussion of the conflict between the labor and antitrust laws necessarily deals with fundamental questions of economic and political policy. Competition, because it is a system of private ordering which tends to prevent the concentration of both public and private economic power, makes an invaluable contribution to pluralism and democracy. In a sense, it imposes a kind of democratic process on the operation of the economy. Collective bargaining, fostered in the belief that unorganized labor markets create an "industrial absolutism," has similar aims. The control of labor markets through collective bargaining, however, may require limitations on competition. What is more, that institution creates anti-competitive incentives and breeds power far beyond that necessary merely for meaningful control of labor markets. ${ }^{17}$ And because labor and management are unified by their mutual interest in seeing competition limited, collective bargaining often leads to the imposition of substantial restraints on product markets. It is necessary, therefore, to examine the components of this conflict among policies.

\section{A. Product Competition and the Control of Labor Markets Through Collec-} tive Bargaining

Collective bargaining is often justified in part as a device for curing alleged imperfections in free labor markets, but it is hardly designed to eliminate these

16. See Statement by Louis D. Brandeis before United States Commission on Industrial Relations, S. Doc. No. 415, 64th Cong., 1st Sess. 7659 (1916).

17. This relationship has been the subject of no little body of literature. See, e.g., Lindalom, Unions and Capitalisa 85-109 (1949) ; Machlup, The Political Economy of Monopoly 333-435 (1952); Mason, Economic Concentration and the Monopoly Problem 196-218 (1957); Dunlop, Wage Deterartatation Under Trade Unions 95-121 (1944); McKie, Collective Bargaining and the Maintenance of Market Competition, in The Public Stake in Union Power 86 (Bradley ed. 1959); Simons, Some Reflections on Syndicalism, 52 J. Por. EcoN. 1 (1944). For material on anti-competitive activities by unions in the coal and garment industries, see generally BARATz, THE UNION AND THE Coal Industry (1955) and Braun, Unton-Management Co-operation (1947). 
directly. ${ }^{18}$ It does not generally irccrease the mobility of employers and employees ${ }^{19}$ or improve the channels of communication so that information is more accurate and plentiful. As far as employer collusion is concerned, collective bargaining may well mitigate its harsh effects, but it surely does not purposefully prevent the act itself, as the familiar institution of multi-employer bargaining amply demonstrates. Nor do unions generally seek to improve wages and working conditions through control and manipulation of the total supply of labor in particular labor markets. Their aim, rather, is to control the behavior of employers directly by organizing the employees of particular firms and compelling favorable settlements by strikes or other means. ${ }^{20}$ Unemployment within a particular labor market, therefore, is unlikely to be a significant obstacle to union aims until a substantial number of union members are affected. ${ }^{21}$

Because unionism is directed at controlling the behavior of particular firms rather than labor markets, unions have little functional economic significance apart from those firms, a fact of enormous significance for the institution of collective bargaining. ${ }^{22}$ Since unions operate through firms, their bargaining power and the ease with which their goals may be achieved become largely dependent not only upon the discipline and loyalty of the union membership but also upon the position of the employer in the product market and the character of that market itself. This affects the strength of unions and the nature of collective bargaining in two ways. First, the employer's position in the product market sets a ceiling on union wage goals, since he cannot give what he hasn't got to begin with, regardless of how disciplined and loyal the union members are. ${ }^{23}$ Second, severe product competition inevitably increases employer resistance to union demands and even unionization itself. ${ }^{24}$ Perfect or-

18. The imperfections of the labor market are generally attributed to the lack of meaningful competition between employers for labor. E.g., Cox, LAW aNd tHe NationaI. LABOR PoLICY 1 (1960). Collective bargaining, however, premised on notions of "countervailing power," does not seek to increase that competition but establishes a system of bilateral monopoly. See Galbratth, Amrerican Capitalism 114-15 (Sentry ed. 1962). For a critical appraisal of this approach to labor policy see MAcHuop, op. cit. supra note 17 , at 369-79. Bargaining under bilateral monopoly circumstances will not necessarily lead to a "competitive" wage. See Fellner, Prices and Wages Under Bilateral Monopoly, 61 Q.J. ECoN. 503 (1947).

19. MaCHLUP, op. cit. supra note 17 , at 375 .

20. LINDBLOM, op. cit. supra note 17 , at 62 .

21. Id. at 67-84. Where it is substantial and other circumstances are such that use of the unemployed as strikebreakers is feasible, however, unemployment is a serious threat to union ambitions.

22. See Chamberlain, The Union Challenge to Management Control 99-100 (1948), for a discussion of the implications of this fact in a slightly different context.

23. Full discussions of the relationship of the employer's position in the product market to union "bargaining power" can be found in Dunlop, Wage Deteriminatron Under Trade Unions 74-94 (1944) and Machlup, The Polfrical Economy of Monopoly $344-48$ (1952).

24. Illustrative of this is the experience in the coal industry. See Coronado Coal Co. v. UMW, 268 U.S. 295 (1925) and Baratz, The Union and the Coal Industry 39-74 (1955). 
ganization and discipline of workers is hardly ever possible and the very existence of collective bargaining in some industries may depend upon eliminating the employer's principal incentive-product competition—to exploit advantages in the labor market.

If a union fails to organize along product market lines, wages will become an element of price competition and will tend to the lowest level paid by any employer. The employer who has recognized a union will often be unable to meet even moderate union demands, since his products must compete with those of an employer who has not recognized the union and is exploiting his advantages in the labor market to the full. Under those circumstances, the union, regardless of how disciplined and loyal its members may be, has little or no bargaining power and collective bargaining may be a meaningless institution. To prevent this, the union must either organize along product market lines or exclude, by one means or another, the non-union product from the market.

It is obvious, then, that competition provides employers with great incentive to resist union wage demands. This resistance is likely to extend to other matters, particularly when union organization is not product market wide and the restrictions on employer conduct are not uniformly imposed on all competitors. The temptation to cheat on collective agreements, for instance, is very great when competition is severe. And an employer subject to such competition may well believe that he needs to preserve his right to discipline his work force unchecked so that maximum efficiency can be maintained. He may even resist restrictions on the right to discharge which require a showing of "cause," because he does not want a third party not subject to product market pressures to determine what is "cause" or to have discharges turn on his ability to produce concrete evidence of incompetence, insubordination and the like. The very existence of the unchecked power to discharge, moreover, is itself an effective disciplinary tool. But, more important, the product market imposes no sanctions against abuse of this power unless the replacements are inferior workmen. This does not mean there should be universal restrictions on the right to discharge. It does suggest, however, that in highly competitive industries, product market competition is the greatest single spur to the retention and exercise of discretion by employers; without lessening the competitive pressures on the employer, either by organization along product market lines or other means, unions may be unable to attain even basic non-wage purposes of collective bargaining.

In industries characterized by relatively easy entry and small firm size, the very organization of the union may be endangered by unlimited product market competition. A union can never, as a practical matter, maintain perfect organization and discipline if a substantial number of workers and employers is involved. When entry is easy and firm size small, the union may not know of all the employers operating in the product market. And even if they discover their location and organize their employees, the continuing flow of newcomers, with their non-union workers, will lead the organized firms to resist union demands and to find ways to destroy the union. And unless employee organization is 
exceptionally-often impossibly-strong, some employers will be able to cheat on collective agreements without the union's knowledge. Under those circumstances, the very existence of collective bargaining may well depend upon the union's securing control of the product market. In the garment industry, for instance, the contractor system creates just such a problem since entry for a contractor is easy and the size of the operation is generally very small. To maintain their organizations and collective bargaining, the unions have found it necessary to control those who hire the contractors. ${ }^{25}$ This control enables them to regulate entry and see that the contractors comply with the union scale by fixing the price they receive.

Competition's threat to union goals is aggravated by the fact that cyclical swings of the economy have an uneven impact on wages. Studies of the depression indicate that wages fell first in the most competitive industries, particularly when the buyers of the product had sufficient bargaining power to force price concessions from the sellers. ${ }^{26}$ Where the sellers had greater bargaining power, price declines were slower in coming, and wages did not fall as quickly. In short, employees in the garment industry may be in a far more vulnerable position than those in steel. ${ }^{27}$ Thus, unions in competitive industries have great incentive to restrain competition between employers as a matter of self-defense. If the employers in the industry have less bargaining power in the product market than the buyers, they will attempt to strengthen their employers by restricting competition among them. Unions will also desire to moderate the intensity of cyclical variations, because sharp downswings increase the competitive pressures on employers. These will, absent union control of the product market, be translated into pressures against the union which may threaten to destroy collective bargaining entirely. One union-inspired device designed to mitigate such pressures was the Mine Workers "willing and able" clause, which allowed the union to withdraw all labor when it pleased. It was designed to limit production and spread the available market between the various firms and workers, thereby preventing an "oversupply" when demand faltered. ${ }^{28}$

\footnotetext{
25. See Braun, Union-Management Co-operation 61-62, 149-55 (1947) and Seidman, The Needle Trades 275-76 (1942).

26. Dunlop, Wage Determination Under Trade Unions 144-48 (1944).

27. This places an important qualification on Galbraith's statement that "it was the power of the steel industry . . . that brought the United Steelworkers into being." GaLbrattr, American Capitalisar 115 (Sentry ed. 1962). He does recognize that some unions "have emerged as a supplement to the weak market position of the operators and manufacturers," id. at 116, but seems to assume that power in the product market inevitably leads to exploitation of advantages in the labor market and vice-versa. This by no means follows, however, for firms with large resources and secure competitive positions have less incentive to maximize advantages in the labor market than marginal employers. The latter are compelled by product competition to require more from their workers and to resist all restrictions on their discretion in any market. Union-imposed restraints on competition in highly competitive industries, therefore, are designed not only to bolster the weak market position of the employers but also to lessen their incentive to resist unionization.
}

28. Baratz, The Union and the Coal Industry 140 (1955). Because of legal and other difficulties, see Penello v. International Union, UMW, 88 F. Supp. 935 (D.D.C. 


\section{B. Union Monopoly in Product Markets}

Whereas the previous section was designed to show that the very existence of collective bargaining might compel some restraints on competition in order to establish control of labor markets, this section will demonstrate there is no limit on union incentive, and frequently on union power, to impose monopoly on product markets.

That the revenue a firm receives will ultimately impose a limit on the money aims of a union is obvious. A union, therefore, will inevitably be interested in increasing that revenue, and in that sense, the long-run interests of the firm and the union are not divergent. For this reason, unions have great incentive to organize the employees of all the employers within the particular product market. They are then better able to impose higher labor costs since all the competing employers may, to a point, ${ }^{20}$ share more or less equally in the greater burden. They can, moreover, maximize the revenue of the group through such familiar monopolistic devices as price-fixing and exclusion of newcomers. It would seem then that unions have almost no stake in the maintenance of competition between employers. If an employer which has recognized the union is driven out of business by competition, the union not only ends up with unemployed members but also has the worry and expense involved in organizing the employees of any newcomer. Thus, in most instances, the union would prefer to protect the first employer and exclude the newcomer. So long as employers are faced with the insecurity associated with competition, the temptation to resist union demands or to cheat on collective agreements will exist. But the "enlightened" employer whose position in the product market is secured by union-imposed restraints on competition will make a fine collective bargaining partner.

Collective bargaining, therefore, creates anti-competitive incentives. Given sufficient union organizational capabilities, it also creates the necessary power. A union is admirably suited for the policing of an anti-competitive scheme. It formulates policy, has access to information in the product market as a whole and acts in that market. Moreover, the power it can exercise is at once swift, drastic, and selective. The price cutter faced with a union determined to restrain competition does not choose between maintaining price and initiating a price war but between maintaining price and having serious labor trouble. A union, therefore, by using any one of the many economic weapons available to it, is able to impose a very direct and effective sanction on any firm which attempts to disrupt an anti-competitive scheme.

1950), this scheme was abandoned for another arrangement. See notes 185-86 infra and accompanying text.

A similar device in the garment industry is the ILGWU's contractor designation system. See note 36 infra.

29. There are limits on such a strategy, since uniform wage raises rarely, if ever, have a perfectly uniform impact on competing employers because of differences in production methods and the like. Large firms with high worker productivity as a result of automation, for instance, will gain a competitive advantage over small firms which rely more on labor than capital. 
Empirical evidence bears out these conclusions. There have been many instances of direct or indirect price-fixing by unions. The photoengravers, for instance, have had clauses in collective agreements which barred sales by employers at a price less than the cost of production. ${ }^{30}$ ILGWU contracts provide that the price paid by the jobber or manufacturer to the contractor be sufficient to cover the labor costs involved plus a reasonable amount for overhead. ${ }^{31}$ In the construction industry, there have been many instances of union involvement in price-fixing or bid-rigging schemes. ${ }^{32}$ Other union-inspired devices have been designed to exclude competitors and thereby provide certain employers with sheltered markets. A. familiar example is the refusal by unions in the construction industry to install or work on material not manufactured by members of the local union. ${ }^{33}$ "Area standards" picketing and secondary boycotts of retail establishments selling non-union goods may also be directed to this end. Another common device is the "most favored nation clause" which conditions employer agreement upon union enforcement of the same terms on competitors. ${ }^{34}$ The deliberate use of high labor costs by the Mine Workers to drive out smaller mines is also directed at changing the character of competition in the product market. ${ }^{35}$ Some unions, particularly those vulnerable to cyclical variations in the economy, are prone to market sharing schemes. The ILGWU's control over the jobber's hiring and assignment of work to contractors ${ }^{36}$ and the UMW's "willing and able" and "memorial day" clauses ${ }^{37}$ are designed

30. Dunlop, Wage Determination Under Trade Unions 104-05 (1944).

31. The agreement between the National Dress Manufacturers' Association, Inc., and the Joint Board of Dress and Waistmakers' Union of Greater New York, ILGWU, provides that any jobber or manufacturer hiring a contractor must pay the contractor an amount sufficient to cover the wages required by the collective agreement and a "reasonable".amount for the contractor's overhead and services. UNION CoNT. REP. I 56,812.35 (1961).

See also Greenstein v. National Skirt \& Sportswear Ass'n, Inc., 178 F. Supp. 681 (S.D.N.Y. 1959).

32. E.g., Local 175, Int'1 Bhd. of Elec. Workers v. United States, 219 F.2d 431 (6th Cir. 1955); Las Vegas Merchant Plumbers Ass'n v. United States, 210 F.2d 732 (9th Cir. 1954).

33. Easily the most celebrated instance was involved in Allen-Bradley Co. v. Local 3, Int'l Bhd. of Elec. Workers, 325 U.S. 797 (1945).

34. These clauses have many variations. Under one form, the union binds itself not to enter into agreements with other employers unless they contain the same terms as the basic contract. Agreement between Bituminous Coal Operators' Ass'n and UMW, UNroN CoNr. REP. If 56,161.65(A) (1958). Another allows renegotiation by the employer if competitors secure more favorable terms from the union. Agreement between Diamond Milk Products, Inc. and Local No. 379, Dairy Workers, Union Cont. Rep. T 56,011.12 (1959).

35. Baratz, The Únion and the Coal Industry 70 (1955). See Lewis v. Pennington, 1961 Trade Cas. $\{70,036$ (E.D. Tenn. 1961).

36. ILGWU contracts limit the number of contractors available by designating certain ones to particular jobbers and manufacturers who are then prohibited from using others. When a jobber or manufacturer does not have enough work for all his designated contractors, he must divide what he has equally between them. UNION Cont. REp. If 56,812.11 (1961).

37. See note 28 supra. 
to spread the work among all the firms and workers when demand for the product weakens. In short, they "stabilize" production in bad times.

It seems clear, therefore, that union imposed restraints on competition are neither accidental nor rare. Unions have little interest indeed in maintaining product market competition, for, from their point of view, competition between employers is little different from competition between union members. An examination of the type of industries in which unions do not impose explicit controls on the operation of the product market demonstrates this clearly. As in the case of steel, the structure of these industries is typically oligopolistic. Employers have sufficient market power and price control to render direct union intervention unnecessary. ${ }^{39}$ Since competition does not pose a threat to union organization or its wage goals, union concern over the product market is usually negative and limited to insuring that the market structure is not upset by the action of a "maverick" firm. Reinforcement of oligopolistic structures, however, while it may not require observable union intervention, is not unimportant to the suppression of competition.

The anti-competitive effect of collective bargaining does not rest solely on strike threats or overt regulation of the product market. Multi-employer bargaining requires collective judgments by employers as to future wage levels. How these can be reached without collective consideration of future prices is by no means clear. Furthermore, if the potential "aggressor" in a price war is at all aware of the interrelationships of his markets, the existence of a unionapart from any explicit threat on its part-will weigh heavily against a decision to upset the status quo. He must bargain periodically, if not continually, with the union and his position in that respect will be seriously impaired if his conduct has introduced large elements of insecurity into the market. The impact on competition is not measurable but it may well be as significant as that of the more observable and explicit restraints on competition described above.

\section{Collective Bargaining and Democracy}

If we lived in a one-value society, and that value were competition, little more need, or could, be said. Collective bargaining would be sacrificed in the name of competition. But so long as we desire to opt for pluralism, voluntarism, and consent rather than coercion, we will always be faced with the need

38. McKie, Collective Bargaining and the Maintenance of Market Competition, in Bradley, The Public Stake in Union Power 86, 93 (1959).

Arguably, a union might prefer more competition, rather than less, in an oligopoly situation since competition would lessen the employers' staying power and ability to withstand a strike in bargaining situations. This is true, however, only when union organization and control of the working force is so complete and reliable that no foreseeable employer resistance can shake it. That is usually not the case, however, and to the extent the union does not have such complete power over every firm, competition, because it increases employer incentive to resist unionism, is more of a threat than a benefit. There is, moreover, a correlation between the number of firms and the costs and difficulties of maintaining union organization. To the extent, therefore, that increased competition entails an increase in the number of firms, unions have a further reason for opposing it. 
to accommodate clashes between competing values and claims at the least cost to the society as a whole. One such clash involves the status of the employed worker. It has created problems of varying acuteness in every industrialized nation of the world. Because political and social status are profoundly related to occupational status and environment, a labor policy in a democratic society necessarily deals with far more than factors of production-it must take into account the role of the employed worker in a democratic system. ${ }^{39}$

The employment relationship is typically regarded as a relationship of inferiority. ${ }^{40}$ Symptomatic of this belief is the deeply ingrained notion that unorganized labor markets are not competitive and somehow load the dice against the employee.41 One reason often asserted in support of this notion is that labor markets operate on a quoted price system; because the employer does the quoting, he is said to have a strategic advantage. ${ }^{42}$ This belief has surely been strengthened by the attitude of employers themselves; they talk and behave as though they have discretion in the fixing of wages and working conditions. The very existence of "wage policies" is a familiar example of discretion which does not exist in the competitive model. Similarly, the behavior of certain employers in raising wages and improving working conditions when faced with union organizational drives lends support to the conclusion that unorganized labor markets do not impose any fixed price-as does the competitive model-from which deviation is either impossible or irrational.

Another reason for believing that free labor markets operate to the disadvantage of employees-one which deserves special mention because of its enormous influence on the attitude of the labor force and the course of collective bargaining in the United States-is the power of the foreman in the unorganized labor market. The foreman, even though on the lowest rung of the management hierarchy, often has the power to hire, fire and set wages, subject only to very broad limits established by top management. ${ }^{43}$ The result is that the livelihood

39. Labor is a factor of production-but the worker is a human being, and his work involves social as well as technical relations. Work is not merely the way to get a living, but a way of life, a game or a thralldom, a field of conflicts and loyalties, anxieties and reassurances, prestige and humiliation. ... The occupational and social structures are interlocked.

Phelips Brown, The Economics of Labor 5-6 (1962).

40. See generally id. at 30-38.

41. - E.g., Cox, Law and the National Labor Policy 1 (1960); see also note 16 supra. For a criticism of many of the allegations made as to unorganized labor markets, see Machlup, The Political Economy of Monopoly 348-69 (1952).

42. E.g., Dunlop, Wage Determination Under Trade Unions 11-12 (1944).

43. Although U.S. Steel established central employment offices in 1919, control of jobs, the rotation of work, was left in the hands of foremen. In stable periods this power is relatively unimportant. In a depression-ridden steel town, where getting a day's work has been as prized as finding a nugget, it increased in importance a thousandfold. ... The power to assign work in such a situation means the difference between living or being destitute to the man who receives it, and the reminiscences of steelworkers are filled with stories of money lent to foremen after a better-than-usual 
of the individual worker often depends not on his contribution to production but upon the favor with which his foreman views him. This can lead to wage differentials between individual workers in the same plant, performing the same work, with the same skill. It can also lead to arbitrary discharges and the requirement of "kickbacks" to foremen as the price for retaining a job, Unchecked power of this nature performs no industrial function and serves merely to demonstrate the imperfections in the operation of free labor markets.

Take discharges, for instance. If a foreman discharges men on the basis of favoritism or the failure to comply with a "kickback" system, a reasonably competitive labor market will impose a sanction on the employer. Since men generally desire not to be subject to arbitrary and capricious authority, the employer should find the conduct of his foremen has substantially lessened the number and quality of those who seek jobs in his firm. But the unorganized labor market rarely visits such a sanction upon the employer, and the exercise of unchecked authority by foremen may continue until collective bargaining is introduced. It is of no little significance that among the first tasks of a newly recognized union in this country is to establish systems of job classifications which bring to light arbitrary differentials, to set up "fixed" seniority rules governing lay-offs and to restrict the employer's right to discharge. ${ }^{44}$

While it is by no means absolutely clear that labor markets do operate to the disadvantage of the worker, the assertion should not be peremptorily dismissed. Apart from problems of immobility, ${ }^{45}$ there is a vast difference in

pay, and never repaid or expected, of minor officials who have small business interests that men patronize in the hope of getting more work.

The U.S. Steel Corporation: III, Fortune, May, 1936, p. 141, quoted in ChaMrberLaIN, The Union Challenge to Managemsent Control 94 (1948).

44. Chamiberlain, The Union Challenge to Managemient Control 93-94 (1948).

45. Immobility of both employers and employees prevents the desired response to differentials in wages and working conditions within and between labor markets. Worker immobility results from several factors. The first, and most important, is that the number of feasible employment opportunities a worker has is severely limited by his need to get to work and home again relatively easily. See Brown, E.H.P., THE Econorrics of LABor 96 (1962). To increase the number of opportunities available, he must have resources sufficient to move himself and his family. If he is unemployed, or in an area in which wages have been depressed by substantial unemployment, this may be impossible. A further. inhibiting factor is the lack of information. See note 47 infra.

Employee immobility in terms of responding to job differentials is one factor, therefore, which may cause free labor markets to deviate from the competitive model. This immobility, moreover, because of the lack of accurate information, exists both between and within particular labor markets. But two other factors should be noted. Even in the competitive model, there does not have to be universal mobility since equalization of differentials would not require movement of all the employees in one market or company to the better market or jobs. See Machlup, The Political Economy of Monopoly 357-58 (1952). It is also necessary, at least in terms of justifying collective bargaining, to distinguish between institutional obstacles to mobility and sheer unwillingness to change.

Many of the consequences of employee immobility would be mitigated if employers were sufficiently mobile to respond to differentials in a way which tended to equalize them. But they also lack accurate information as to the prevailing working conditions and the 
numbers between the buyers and sellers of labor and it is impossible to set an individual price for each day's labor by each employee. Labor markets tend, therefore, to operate as quoted price systems both as to wage and non-wage matters. ${ }^{46}$ That the buyers of labor quote the price might not be disadvantageous to the sellers were it not for the fact the latter generally do not have accurate information as to alternative prices and non-wage aspects. ${ }^{47}$ This means, in turn, that each firm may have some discretion in setting the price for labor and is in fact a limited labor market itself. This discretion may well work to the disadvantage of the seller.

As Adam Smith recognized,48 labor markets also invite collusion between employers to control and depress working conditions. Other factors aggravate the situation. Employers as a class rarely believe they should, or do, compete for employees, an attitude hardened by the lack of a public policy designed to maintain or promote such competition. Collusion in the labor market, therefore, may appear to them to be not only profitable but part of the natural order of things. Moreover, the level of wages and working conditions in particular labor

quality of the labor available in other markets. Employers too face a problem in resources since a change from one labor market to another may involve abandonment of an existing plant and creation of a new one. Moreover, the employers whose mobility is important are ones which deal in a geographically large product market and hire a large number of employees. But the entry of such an employer into a local labor market might push wages up to the point where the initial incentive for a change was destroyed. It should be noted that whereas the response of employees to differentials is inhibited both between and within labor markets, the barriers to employer mobility operate only between those markets.

Much has been made of the problems immobility creates in unorganized labor markets. But to the extent this immobility results from inadequate systems of communication and transportation technological achievements of recent years must be taken into account. Studies should also be made of the effect of public and private institutions devoted to the systematic allocation of employers and employees to various markets.

46. See Dunlop, Wage Determination Under Trade Unions 11-12 (1944).

47. Information as to alternative jobs must come either from employers or other workers. If the demand for labor is high and employers are actively competing, they may advertise or employ other media to convey information about job openings to job seekers. One does not have to be entirely cynical to realize the information conveyed is not always going to be accurate. If employers want to get workers to move from one labor market to another, they will probably try to get more than are actually needed so that wages will ultimately be depressed. If they are only trying to get people to change jobs within a particular labor market, other pretenses may be practiced. Working conditions or the nature of the job may be distorted. One common practice today, for instance, is to hire someone on what appears to be a permanent basis knowing it will last only a short time. It is all very well to say that the market will impose a sanction for such conduct since other workers will learn what has happened in the past and avoid those particular employers. But how to they learn what has happened in the past or what alternatives there are if information derived from employers is unreliable? Usually they must learn by word of mouth from other workers. But this information is likely to be highly inaccurate, incomplete and quite subject to distortion by the prejudices of the one conveying the information, particularly when it concerns non-wage aspects. All of this, moreover, is severely aggravated by the fact that the employee's value in the market place will be diminished if he changes jobs very often.

48. Snite, The Wealth of Nations 66-67 (Mod. Lib. ed. 1937). 
markets is often established by a few large employers who represent only a small number of industries. Because they hire so many workers and the community's prosperity is so often closely related to their economic well-being, they are rarely subject to meaningful competition from other local employers and, hence, can set the "high wage." Because most of these large employers are not engaged in widely diversified industries, their demands for labor are unlikely to be divergent at given times, and their common interest in a collusive arrangement, explicit or implicit, is usually great. This is particularly so if the meaningful competition at the product market level is not between these particular employers but between them as a group and groups of employers in other labor markets. ${ }^{49}$ Employer collusion, therefore, is very likely to be a large factor creating an imbalance against the worker in free labor markets, particularly since, in the absence of organization, workers have little or no staying power and cannot offer even token resistance to such collusive arrangements.

The political and social consequences of the foregoing are as grave for a democratic society as are the economic results. Political democracy requires a citizenry jealous of its rights but content with the basic system because of a belief in its essential fairness. If the lives and well-being of a substantial portion of the population are thought to be subject day after day in a most personal way to economic power which can be, and often is, exercised arbitrarily, democracy itself is endangered. Either the workers will lose, in the words of Brandeis, their "manhood," 50 and become submissive politically as well as economically or they will turn to violence and the system itself will be overthrown. The principal function of collective bargaining, as it has developed in the United States, is to preserve and develop that "manhood" along with a belief in the system's fairness. The resolution of the controversy over internal union affairs makes this evident. Considerations relating to stability and order in industrial relations were, in large part, abandoned for the sake of individual rights.

Some commentators, understandably concerned with the power and incentives created by collective bargaining, have tended to minimize the imbalances of the labor market. 51 Some believe they are "transitory"52 and that in the long run labor markets will allocate human resources reasonably well and without substantial unfairness. This might be true since industrial societies of employees are a relatively new phenomenon. But even so, that is not decisive. For one thing, if democracy depends upon an existing consensus as to the essential fairness of the system as a whole, the long run may simply be too long. For

49. This has been largely true of the coal industry. Baratz, THE UNron AND THE COAL Industry 31-37 (1955).

50. See note 16 supra.

51. See generally Lindblom, Unions and Capitalisa (1949) and Machlup, The Political Economy of Monopoly 348-69 (1952). Lindblom ignores the problem entirely, apparently on the assumption that it does not exist. Machlup, on the other hand, treats it in detail and concludes that employers have some, but not many, advantages in the labor market.

52. Simons, Some Reflections on Syndicalism, 52 J. PoL. Econ. 1, 7 (1944). 
another, while the imperfections of the labor market are of enormous importance to an understanding of collective bargaining, they are in large part only symptomatic of the whole problem of the status of the employed worker in a democratic society. ${ }^{53}$ Collective bargaining performs far more than the negative, but nevertheless important, function of blunting the impact of the unorganized labor market's imperfections by providing a rough balance of power and a relatively orderly means of reaching economic decisions in what would be an otherwise chaotic market. As it has developed, it plays a positive role in educating and preparing the employed worker for participation in the democratic process and in providing a device through which he can seek a bigger share of the "social sovereignty." "It If it has done nothing else, collective bargaining has gained employee consent to the system as a whole, and that is no small achievement. Further, these achievements have been reached through institutions composed largely of private groups engaged in private ordering, a process consistent with notions of diffusion of power and pluralism.55

This is not to say that collective bargaining is either sacred or unchangeable. It is to suggest, however, that some limitations on competition may well be a small price to pay for what collective bargaining contributes to democracy. The alternatives involve grave dangers. Legislation directly fixing wages and working conditions centralizes control and does little to develop the "manhood" essential to the maintenance of democratic institutions. Ultimately, since collective bargaining is part of an integrated system, such legislation might have ramifications elsewhere. It might lead to government price-fixing, for instance. Any radical disruption of private institutions, moreover, must always be at a cost to existing freedoms but the ultimate cost will always be unpredictable. Collective bargaining orders such varied relationships as exist in a garment contractor's tiny tenement shop, a longshore shape-up, a carpenter's hiring hall, and an assembly line. Radical tampering with such private institutions will inevitably be at unpredictable prices and for unpredictable gains. While none of this compels absolute retention of the status quo, it does suggest caution. Disruption of important parts of a highly complex and integrated system can lead only to disruption elsewhere. This, in turn, can be as great a threat to democracy as monopoly.

\section{The Irreconcilability of Conflict}

The conflict between competition and collective bargaining creates severe problems of statutory interpretation, as well as critical issues of public policy.

53. As an initial proposition, it is surprising that a society which requires the vast majority of its population to be subject to the beck and call of others for large portions of their waking hours can maintain democratic ideals politically. It is not surprising, however, or undesirable, that such a society has partially sacrificed other goals, such as the free market, in order to accommodate the economic needs of the industrial system to the political and social demands of democracy.

54. Perlman, The Principle of Collective Bargaining, in Unions, Managenent and the Public 45 (Bakke, Kerr \& Anrod ed., 2d ed. 1960).

55. Frey, Democracy, Free Enterprise and Collective Bargaining, in Labor Relations AND THE LAW 24 (Wollett \& Aaron ed., 2d ed. 1960). 
The two principal statutes embodying these policies fail even to acknowledge each other's existence or the possibility of conflict. The Sherman Act allows no scope for countervailing considerations-such as the need to protect and maintain collective bargaining relationships-once the intent to restrain trade is proven. ${ }^{56}$ In short, application of Sherman Act standards would seriouslyand probably decisively-impair collective bargaining.

The National Labor Relations Act, on the other hand, is concerned entirely with regulating what it conceives to be a struggle for power between unions and employers. And, except for the emergency dispute problem, ${ }^{57}$ it contemplates that a clash between the interests of labor and the interests of management will protect the public by neutralizing the market power created by collective bargaining. This is utterly unrealistic, however. Whatever conflict there may be between labor and management is over the division of the spoils, not their creation. And where their creation depends upon union enforced controls on the product market, it is not difficult for labor and management to work out a quid pro quo governing their division. In the coal industry, for instance, the big mines had little to gain from resisting the UMW's 1950 demands for higher wages since they were tailored to the larger firms' ability to automate and were in part intended to wipe out the smaller operators. ${ }^{.8}$ To some extent, the same may be true in the oligopolies even though the product market controls are not solely the result of union restrictions. Strikes may be timed to coincide with variations in demand for the product so as to keep prices at a high level, and unions in any event add a measure of "stability" to the market structure. Strikes and wage demands, moreover, may play a large role in preventing the development of a national consensus as to the effect of oligopolies and as to the remedies appropriate for mitigating their undesirable features.

Because of the irreconcilable nature of the policy conflict and the statutory indifference to the problem, there is no principle upon which we can distinguish "legitimate" collective bargaining activity from "illegitimate" monopolization. Price-fixing may be designed to assure compliance with the terms of a collective agreement by seeing to it that the employer has sufficient funds to pay the required wages. ${ }^{59}$ Products may be excluded from a local market because they were manufactured under "sweatshop" conditions and would, if allowed tc compete freely, destroy even a modest union wage scale. Share the work programs may spread the available work among all the workers so that none of

56. Congress has not left us with the determination of whether or not particular pricefixing schemes are wise or unwise, healthy or destructive. It has not permitted the age-old cry of ruinous competition and competitive evils to be a defense to pricefixing conspiracies.

United States v. Socony-Vacuum Oil Co., 310 U.S. 150, 221 (1940).

See note 224 infra and accompanying text.

57. See 61 Stat. 155-56 (1947), 29 U.S.C. $\S \S 176-80$ (1958).

58. And in fact there has been no major coal strike since then. See Lewis v. Pennington, 1961 Trade Cas. \ 70,036 (E.D. Tenn. 1961). 1959).

59. See Greenstein v. National Skirt \& Sportswear Ass'n, 178 F. Supp. 681 (S.D.N.Y. 
them have to bear the whole burden of bad times and marginal employers are not compelled to attempt to "break" the union. But each of these schemes may also be designed to impose a "monopoly" upon the public. These ends can be distinguished only by determining whether wages and prices are too "high." Nor can a distinction be made between union activities in the labor market and activities in the product market. ${ }^{61}$ High wage demands were used by the UMW to exclude smaller mines while "memorial days" limited production as a means of keeping prices up. But wage demands and preservation of the right to refuse to work are common labor market activities, whatever their impact on product competition may be. Whatever distinctions are employed for purposes of regulation must, therefore, be largely arbitrary, for there are no generalized principles which harmonize the conflicting policies. And since it is generally desirable for the courts, in the absence of legislative guidelines, to rely on principle in the exercise of their function, their responsibility in this area should be carefully defined.

\section{Judicial Regulation of Union Activities Under the Sherman Act}

From the beginning, the courts have used the Sherman Act as a vehicle for the regulation of union activities. Early decisions, reflecting a decidedly antiunion judicial bias, went beyond notions relating to product competition and were in fact part of a judicial attempt to formulate national labor policy. But this period continues to have its impact on the law, for it labeled the Sherman Act as a weapon of class war and assured that it would be an emotional symbol to future generations. This in turn has a had a large impact on the doctrinal paths followed by later cases, which, although they have stuck more closely to traditional purposes of the Sherman Act, have created further confusion. A striking example is the Allen-Bradley decision, ${ }^{62}$ the latest climax in the development of union liability under the antitrust laws. This section will deal with what the courts have done in seventy odd years of relatively continuous litigation, for that is vital evidence of the responsibilities they can and should be asked to undertake in dealing with legislative policies which cannot be reconciled through principled distinctions.

\section{A. The Courts, Labor and the Sherman Act: 1890-1931}

The Sherman Act "was enacted in the era of 'trusts' and of 'combinations' of businesses and of capital organized and directed to control of the market by

60. Take hot cargo clauses, for instance. In terms of competition, these can be drastic restraints for they can be used to exclude certain firms from a market thereby sheltering others from competition. The maintenance of meaningful collective bargaining, on the other hand, may compel their use since the excluded firms may pay extremely low wages which are reflected in the product price. A per se rule, whether permitting or proscribing them, merely abandons one policy in the name of another. An "accommodation" of the policies, however, must look to the "reasonableness" of the protected wage scale and the price of the union made goods.

61. See Mason, Economic Concentration and the Monopoly Problem 216 (1957).

62. Allen-Bradley Co. v. Local 3, Int'l Bhd. of Elec. Workers, 325 U.S. 797 (1945). 
suppression of competition in the marketing of goods and services, the monopolistic tendency of which had become a matter of public concern."63 But however hesitant and tentative the federal courts may have been initially in applying the statute to business activities, no such reluctance was evidenced when the defendant was a union. Between passage of the statute in 1890 and the decision of the Supreme Court in the Trans-Missouri Freight case in 1897, lower federal courts found unions in violation twelve times while only one violation was found involving a business. ${ }^{64}$ This development was capped in 1908 when the Supreme Court squarely held that the Sherman Act applied to union activities.

Whatever one may think of the result reached in Loewe v. Lawlor, ${ }^{65}$ it can hardly be disputed that the opinion, although unanimous, is one of the most unsatisfactory efforts in the history of the Court. Without reasoning, analysis, or even appreciation of the importance of the question, the principal result was asserted in such a summary fashion that careless readers, blinded by the verbosity of the rest of the opinion, miss the pertinent discussion entirely. The Court, through Mr. Chief Justice Fuller, said :

The act made no distinction between classes. It provided that "every" contract, combination or conspiracy in restraint of trade was illegal. The records of Congress show that several efforts were made to exempt, by legislation, organizations of farmers and laborers from the operation of the act and that all these efforts failed, so that the act remained as we have it before us. ${ }^{66}$

The subsequent history of the Sherman Act, however, undermines the Court's literal reliance upon the word "every." And, as for the legislative history, the Court's statement is misleading. The amendments exempting labor were passed by the Senate but involved a bill outlawing "combinations . . . which tend to advance the cost to the consumer. . . ." Br Because this bill became overladen with amendments which were irrelevant to the issue, of dubious constitutionality, and in part intended to cause its ultimate defeat, it was returned to the Judiciary Committee for further consideration. ${ }^{68}$ The Committee then produced what is now the Sherman Act. No further attempt was made to add the labor amendments, apparently because of a belief that the new bill, which did not refer to pressures on consumer prices, could not be read to encompass unions. ${ }^{69}$ This is not to say the legislative history of the Sherman Act shows a clear intent to exempt labor, for there is room for speculation as to why Congress did not return to the question. It is to say, however, that the opinion never at-

63. Apex Hosiery Co. v. Leader, 310 U.S. 469, 492-93 (1940).

64. United States v. Trans-Missouri Freight Ass'n, 166 U.S. 290 (1897). See also Berasan, Labor and the Sherman Act 3 (1930), and cases cited therein.

65. 208 U.S. 274 (1908).

66. Id. at 301.

67. 21 Cong. Rec. 2611 (1890).

68. Id. at 2728-31. See generally BerMan, op. cit. supra note 64, at 22-41.

69. Beraran, op. cit. supra note 64 , at $35-41$. 
tempted to give a fair reading to the actual legislative history and was in error in stating ". . . the act remained as we have it before us." "70

If the opinion in Loewe v. Lazvlor is not clear as to why the Sherman Act applied to union activities, it is equally obscure as to which of them it proscribed. Although the case involved secondary activity, much of the reasoning emphasized such effects as the interruption of interstate traffic, which might result from primary strikes. ${ }^{71}$ Two lower court decisions upon which the Court relied heavily were based on just such reasoning. ${ }^{22}$ In fact, the opinion gave no assurances that unions might not be illegal organizations under the Act. ${ }^{\text {73 }}$ Congressional intervention, however, resolved this particular question.

Section 6 of the Clayton Act, passed in 1914, provided that the antitrust laws should not be construed to prohibit the existence of labor organizations or to prevent them "from lawfully carrying out the legitimate objects thereof."74 Section 20, the anti-injunction provision, barred use of injunctions by federal courts "in any case between an employer and employees, or between employers and employees" involving a dispute over terms and conditions of employment. ${ }^{75}$ It specifically prohibited issuance of injunctions against certain activi-

70. From that day to this, Locwe $v$. Lawlor has served as the foundation of all judicial regulation of union activity under the Sherman Act. In light of this, it is relevant to note that the adversary process broke down in the case, for the Court's view of the legislative history seems to have been largely, if not entirely, shaped by erroneous assertions in the employer's brief which were neither challenged nor refuted by counsel for the union. BERMAN, op. cit. supra note 64 , at 81-87. While adequate presentation by the union's counsel might not have changed the result, their failure to bring relevant material to the Court's attention may well account for the unanimity of the opinion and the summary nature of its reasoning.

In light of what ultimately occurred as a result of this decision, moreover, the breakdown of the adversary process may well have implications for the role of the courts in formulating matters such as labor policy through the process of litigation. For if such an obvious error by counsel can have such important consequences for future generations, there is no protection against less apparent errors so long as courts continue to believe themselves competent to resolve fundamental policy matters in such areas.

71. .... for the direct purpose of destroying such interstate traffic defendants combined. . . . If the purposes of the combination were ... to prevent any interstate transportation at all, the fact that the means operated at one end before physical transportation commenced and at the other end after the physical transportation ended was immaterial.

208 U.S. $274,300-01$.

72. United States v. Workingmen's Amalgamated Council, 54 Fed. 994 (C.C.E.D. La. 1893), aff'd, 57 Fed. 85 (5th Cir. 1893) (general strike in New Orleans); United States v. Debs, 64 Fed. 724 (C.C.N.D. IIl. 1894), aff'd on other grounds, 158 U.S. 564 (1895) (widespread railway strike).

73. See Hitchman Coal \& Coke Co. v. Mitchell, 202 Fed. 512 (N.D. W. Va. 1912), rev'd, 214 Fed. 685 (4th Cir. 1914), rev'd, 245 U.S. 229 (1917), in which the district court ordered dissolution of the UMW as a common law conspiracy and direct violation of the Sherman Act.

74. 38 Stat. 731 (1914), 15 U.S.C. $\$ 17$ (1958).

75. 38 Stat. 738 (1914), 29 U.S.C. $\$ 52$ (1958). 
ties such as quitting work, persuading others to do the same, etc. But these provisions also were qualified at crucial points by words like "lawfully" and "for lawful purposes." Section 20 ended with the statement "nor shall any of the acts specified . . . be considered or held to be violations of any law of the United States." The naive applause with which labor greeted the Clayton Act is well known, ${ }^{76}$ but the language of the labor provisions, immersed in "lawfuls" and "legitimates," reflected congressional uncertainty as to purpose. The legislative history was equally obscure and for similar reasons. ${ }^{77}$ It was now clear that unions were not illegal organizations even if established along product market lines. Beyond that, however, a court would not be at pains in giving whatever interpretation it pleased to the Act.

Duplex v. Deering, ${ }^{78}$ like Loewe v. Lawlor, involved secondary activity, and the Court found interpretation of the Clayton Act little more troublesome than the Sherman Act. Section 6 obviously did not confer immunity from antitrust liability "where ... [unions] depart from ... normal and legitimate objects. ..."79 The content of legitimacy, however, was a problem left for the courts. Nor was section 20 a bar to judicial intervention, since it was subject to the "general qualifications" 80 restricting its provisions to a "case between an employer and employees, or between employers and employees. . . ." It would do violence to the guarded language employed ... ., "81 said the Court, to interpret section 20 to protect workers other than those "in a proximate relation" to the dispute, i.e., the employees of the primary employer. ${ }^{82}$ In short, unless the Court had been prepared to bar the very existence of labor organizations, the labor provisions of the Clayton Act had little impact indeed.

The Duplex majority failed to admit that there was a real choice between interpretations even at the technical level of canons of construction. Moreover, having failed to acknowledge the patent obscurity of the statute, they did not consider the real issue of the case-the role of the courts in resolving the developing political, social and economic issues of labor policy. The Clayton Act gave the Court an opportunity to re-examine the implications of Loewe v. Lawlor, and its very ambiguities should have cautioned the Court against active involvement in the coming economic and political struggles.

Duplex committed the federal courts to a further decade characterized, perhaps too colorfully but not inaccurately, by the phrase "Government by Injunction." 83 The Clayton Act was not a stalemate for unions. It was an unmitigated disaster. Previously, injunctions had not been available to private

76. See, c.g., Samuel Gompers' famous reference to the Clayton Act as "the Industrial Magna Charta" quoted in WITte, The Government in Labor Disputes 68 (1932).

77. See Frankfurter \& Greene, The Labor Injunction 141-45 (1930).

78. Duplex Printing Press Co. v. Deering, 254 U.S. 443 (1921).

79. Id. at 469.

80. Id. at 470 .

81. Id. at 472 .

82. Id. at 471 .

83. Frankfurter \& Greene, The Labor injunction 1 (1930). 
complainants under the antitrust laws, but section 16 of the Clayton Act unambiguously authorized injunctive relief. ${ }^{84}$ The result of all this is well known. Involvement of the federal courts in the controversy over labor policy diminished their prestige, ${ }^{85}$ and an emotional significance attached to the Sherman Act and the injunction which has not been much diminished by the passage of time.

All of this came about because the Duplex decision wrongly-and, ironically, unnecessarily-committed the federal judiciary to the formulation of national labor policy by reaffirming the Sherman Act as an independent head of federal jurisdiction in labor disputes. ${ }^{86}$ As Mr. Justice Brandeis said in his dissent:

The conditions developed in industry may be that those engaged in it cannot continue their struggle without danger to the community. But it is not for judges to determine whether such conditions exist, nor is it their function to set the limits of permissible contest and to declare the duties which the new situation demands. This is the function of the legislature which, while limiting individual and group rights of aggression and defense, may substitute processes of justice for the more primitive method of trial by combat. 87

Experience under the Sherman Act has demonstrated that fundamental questions of labor policy must be left to the political process. What little consensus there is as to the desirability or appropriate role of collective bargaining is highly variable and largely dependent upon the public's reaction to the allegedly "newsworthy" events of the day. ${ }^{88}$ Formulation of labor policy, therefore, is largely a matter of political power and inevitably partisan. Some aspects of industrial relations, moreover, involve highly technical and complex issues which can be resolved only by an institution capable of giving continuing attention to the problem, such as a legislature through its permanent, supervisory committees. Judicial intervention to the degree foreshadowed by Duple.t is not democratic, unlikely to establish satisfactory rules of law, and may ultinately undermine judicial prestige.

Regulation of union activity under the Sherman Act, however, requires such intervention because the Act itself contains no meaningful guides to judicial action, a fact demonstrated by the "law" fashioned by the courts during this period. One line of cases, principally in the lower courts, seemed to hold that strikes which interrupted interstate traffic, particularly on the railroads, were

84. 38 Stat. 737 (1914), 15 U.S.C. \& 27 (1958).

85. Witte, The GovernMent in Labor Disputes 131 (1932).

86. Because federal courts have only limited jurisdiction, this was of critical importance. Formulation of labor policy by the federal judiciary might have had far less serious consequences had the courts been forced to rely merely on diversity jurisdiction. By using the Sherman Act as a vehicle for establishing federal question jurisdiction over labor disputes, the power of the courts to regulate industrial conflict was greatly expanded. See also In re Debs, 158 U.S. 564 (1895).

87. 254 U.S. 443,488 (1921) (dissenting opinion).

88. See generally Brown \& Myers, Historical Evolution, in SHIster, Aaron \& Summers, Public Policy and Collective Bargaining 1 (1962). 
violations of the antitrust laws. ${ }^{89}$ Although these laws were clearly not intended to prohibit conduct merely because it interrupted commerce or to protect the public against "emergency" strikes, their language can easily be read to prohibit such activity, and many judges showed little reluctance in doing so. As late as 1940 , for instance, a substantial minority on the Supreme Court was quite prepared to hold illegal any strike which prevented the transportation of finished goods in commerce. ${ }^{90}$

Another line of cases prohibited secondary boycotts. ${ }^{91}$ One argument supporting these decisions was that described above, that secondary activity interrupted interstate traffic.92 Another rationale underlying the rule but never clearly stated, seems to have been derived from the common law doctrine of prima facie tort and emphasized the involvement of "innocent" people "remote" from, and "unconnected" with the primary dispute. ${ }^{93}$ Such doctrine, however, has little to do with the preservation of product market competition. Finally, secondary activity by unions was analogized to cases outlawing business collective boycotts. ${ }^{94}$ But as a close student of the antitrust laws has said in regard to the business decisions:

89. E.g., United States v. Railway Employees' Dep't, 283 Fed. 479 (N.D. Ill. 1922) (railroad strike); Williams v. United States, 295 Fed. 302 (5th Cir. 1923) (putting quicksilver in locomotive engines) ; Western Union Tel. v. Local 134, Int'1 Bhd. of Elec. Workers, 2 F.2d 993 (N.D. I11. 1924) (telegraph strike) ; Wagner Elec. Mfg. Co. v. District 9, Int'1 Ass'n of Machinists, 252 Fed. 597 (E.D. Mo. 1918) (munitions plant strike).

90. See Apex Hosiery Co. v. Leader, 310 U.S. 469 (1940).

91. Loewe v. Lawlor, 208 U.S. 274 (1908) ; Duplex Printing Press Co. v. Deering, 254 U.S. 443 (1921) ; Bedford Cut Stone Co. v. Journeymen Stone Cutters' Ass'n, 274 U.S. 37 (1927).

92. See note 71 supra and accompanying text.

93. Duplex Printing Press Co. v. Deering, 254 U.S. 443, 471, 477 (1921). The prima facie tort doctrine, inter alia, prohibited intentional inquiries inflicted through the use of economic pressure unless they were justified by the self-interest of the defendant and only lawful means were employed. The key determinants of liability-justification and lawfulness of the means-however, were matters solely of judicial judgment. See, e.g., Vegelahn v. Guntner, 167 Mass. 92, 44 N.E. 1077 (1896) ; Atchison, T. \& S.F. Ry. v. Gee, 139 F. 582, 584 (S.D. Iowa 1905). See also Holmes, Privilege, Malice and Intent, 8 HARv. L. REv. 1 (1894).

For another apparent use of prima facie tort doctrine in an antitrust context, see United States v. Painters Dist. Council, 44 F.2d 58 (N.D. Ill. 1930), aff'd per curiam, 284 U.S. 582 (1931) (make-work practices).

94. See, e.g., Lawlor v. Loewe, 235 U.S. 522 (1915), citing Eastern States Retail Lumber Dealers' Ass'n v. United States, 234 U.S. 600 (1914), which in turn relied heavily upon Loewe v. Lawlor, 208 U.S. 274 (1908). One great problem with the labor decisions of this era is the failure of the Court to spell out clearly the basis of its holdings. Loewe v. Lawlor, stupra, was based on reasoning which might have proscribed far more than secondary boycotts. See note 71 supra. Duplex Printing Press Co. v. Deering, 254 U.S. 443 (1921), concerned with interpretation of the Clayton Act, seemed to assume that the reasoning in both Loewe opinions was adequate and restricted to the secondary boycott problem and also relied on Eastern States. And except for its emphasis on considerations relating principally to tort doctrine, see note 93 supra and accompanying text, Duplex contributed little to an understanding of the principles being applied by the Court. The next 
Collective boycott, like price-fixing, leaves little scope for the Rule of Reason. A boycott can hardly be incidental to competition or ancillary to some legitimate transaction. Nor does it often raise questions of degree: if it were "only a little" boycott, it would not be worth organizing. ${ }^{.5}$

Such is not the case with secondary activity by unions. Secondary boycotts hurt competitors, of course, but many leave competition undamaged, quite unlike the business cases. ${ }^{96}$ To be sure, secondary activity may be part of an anti-competitive scheme; but it may also be used in situations in which the intent to restrain competition is absent. An unaffiliated local union, for instance, may find it useful in a dispute with the one firm it has organized. The secondary boycott, moreover, when employed in aid of an organizational campaign or a primary strike for higher wages and better working conditions, is "ancillary to some legitimate transaction" in the absence of a finding that organization or higher wages are illegal ends. A per se ban on secondary boycotts, therefore, cannot be based solely on a desire to maintain competition but necessarily stems from a judicial judgment as to how much power unions should have.

A final line, spearheaded by the two Coronado cases ${ }^{97}$ and the decision in United States $v$. Brims, ${ }^{98}$ was specifically directed to the preservation of product market competition and is of considerable importance here. The Coronado decisions involved a lockout followed by union-inspired violence which closed the employer's coal mine. In both decisions, the Court said violence was irrelevant under the Sherman Act, as was the fact that the supply of coal in commerce was reduced by tortious conduct which prevented its production. ${ }^{99}$ What was important, said the Court, was the purpose of the union in closing down the mine. In the first decision, the Court said the evidence tended to demonstrate "a local motive," the lockout and attempt at non-union operation. ${ }^{100}$ At the second trial, new evidence showed that coal mined at non-union wages was a serious threat to the wage policy and organization of the local union, and if that coal could not be excluded from the market, other operators might go non-union. ${ }^{101}$ In order to prevent competition from undermining secondary boycott case, Bedford Cut Stone Co. v. Journeymen Stone Cutters' Ass'n, 274 U.S. 37 (1927), relied on Duplex and the first opinion in Loezwe. But, stung by a Brandeis dissent based in large part on "application of principles of the common law" to determine what is an unreasonable restraint, the Court explicitly said that labor anti-trust decisions were not concerned with notions of prima facie tort as elaborated in the state courts. In short, the Court was consistent only in holding secondary boycotts illegal but wandered aimlessly and endlessly in establishing reasons therefor.

95. Neale, The Antitrust Laws of the U.S.A. 75 (1960).

96. After all, an effective primary strike closes down the main employer and also prevents secondary firms from handling his products, precisely the same result achieved by the secondary boycott.

97. UMW v. Coronado Coal Co., 259 U.S. 344 (1922) ; Coronado Coal Co. v. UMW, 268 U.S. 295 (1925). (Hereinafter cited as First Coronado and Second Coronado.)

98. 272 U.S. 549 (1926).

99. 259 U.S. at $407-13 ; 268$ U.S. at 310.

100. 259 U.S. at 412.

101. 268 U.S. at 308-09. 
established collective bargaining relationships, therefore, the union had prevented the plaintiff from engaging in a non-union operation. This purpose, said the Court through Mr. Chief Justice Taft, was illegal.

The mere reduction in the supply of an article to be shipped in interstate commerce by the illegal or tortious prevention of its manufacture or production is ordinarily an indirect and remote obstruction to that commerce. But when the intent of those unlawfully preventing the manufacture or production is shown to be to restrain or control the supply entering and moving in interstate commerce, or the price of it in interstate markets, their action is a direct violation of the Anti-Trust Act. . . .

[T] he purpose of the destruction of the mines was to stop the production of non-union coal and prevent its shipment to markets of other States than Arkansas, where it would by competition tend to reduce the price of the commodity and affect injuriously the maintenance of wages for union labor in competing mines. ...102

Because illegality of the violence turns on the union's purpose, the Court's reasoning is extraordinarily broad. ${ }^{103}$ It would, for instance, seem to outlaw a peaceable request for recognition made with the same purpose in mind. If the employer complied with the request and abided by the union scale, coal mined under non-union conditions would not enter the market to compete with union-mined coal, precisely the same result achieved by the violence in Second Coronado. The illegal purpose is in fact the very purpose of union organization along product market lines, the existence of which is presumably protected by section 6 of the Clayton Act. Second Coronado, therefore, even though directed to the preservation of product market competition, came perilously close to outlawing national unions entirely.

Needless to say, the Court never went that far, probably out of fear of the political consequences, or, putting it more charitably, because of section 6 of the Clayton Act. But it did decide a closely related case not involving a strike. In United States v. Brims, local manufacturers of millwork who hired union carpenters found their business hampered by the competition of non-union millwork, a situation which created an obvious threat to the union wage structure. The union then agreed with the building contractors in the area that union carpenters were not to be required to work on non-union millwork. Because this arrangement had the flavor of secondary activity and surely was motivated by a desire to prevent non-union goods from competing with union products, the secondary boycott decisions and Second Coronado were ample precedent to support the Court's finding of illegality.

The older cases demonstrate the Sherman Act's inadequacy as a labor statute. The statutory language not only can be read to prohibit almost all

102. Id. at 310 .

103. Conceivably, the decisions can be read merely to prohibit otherwise illegal means, such as violence or fraud, employed for the purpose described. Such an interpretation, however, gives an absurd meaning to the Sherman Act and is not in accord with subsequent decisions based on Second Coronado. See United States v. Brims, 272 U.S. 549 (1926); and Alco-Zander Co. v. Amalgamated Clothing Workers, 35 F.2d 203 (E.D. Pa. 1929). 
union activity but does not even provide standards to guide judicial decisions intended merely to preserve product competition. For as the Coronado line of cases demonstrates, maintenance of competition requires the restriction of collective bargaining. But how is a judge to decide how much collective bargaining we should have or how far competition should be allowed to limit union objectives? Section 6 of the Clayton Act obviously protected collective bargaining and employee organization along product market lines to an undetermined extent, but the Court refused to adopt Mr. Justice Brandeis' position in Duplex which would have left resolution of the issue to the political process.

In no opinion, moreover, did the Court attempt to review the whole body of labor antitrust law and rationalize it in terms of general principles emanating from the Sherman Act. No theories were developed to guide decisions in future cases or to limit future courts in their approach to the problem. Holdings were based upon theories unconnected with each other and, often, with any lasting antitrust principle. In short, the Court's approach was unprincipled. Secondary boycotts and the union's purpose in Second Coronado were held illegal, but close examination would not demonstrate any general principle connecting these two holdings. The theory enunciated in Second Coronado, moreover, could not be elaborated in future cases without open conflict with section 6 of the Clayton Act. Legislation, however, again intervened.

B. 1932-1941:

But this ... has not been considered to be the kind of curtailment of price competition prohibited by the Sherman Act.

The enactment of the Norris-LaGuardia Act ${ }^{104}$ in 1932 was prompted by a belief that the injunction was an inappropriate remedy for resolution of labor disputes and that, by depriving the judiciary of its most effective weapon for the enforcement of court-made labor policy, the substantive law restricting union activities would be effectively nullified, thereby establishing a policy of government neutrality. ${ }^{105}$ But a deeper purpose also motivated Congress. It believed formulation of labor policy was not a proper judicial function ;100 passage of Norris-LaGuardia also "was prompted by a desire . . . to withdraw federal courts from a type of controversy for which many believed they were ill-suited and from participation in which, it was feared, judicial prestige might suffer."107 Following Norris-LaGuardia came the Wagner Act ${ }^{108}$ which gave affirmative protection and encouragement to union organization and collective bargaining and further reflected Congress' desire to narrow the judiciary's role in the formulation of labor policy by entrusting principal enforcement responsibilities to an administrative agency.

104. 47 Stat. 70 (1932), as amended, 29 U.S.C. $\$ \$ 101-15$ (1958).

105. Comment, Labor Injunctions and Judge-Made Labor Law: The Contemporary Role of Norris-LaGuardia, 70 YAlE L.J. 70, 73-74 (1960).

106. Id. at 7476.

107. Marine Cooks v. Panama S.S. Co., 362 U.S. 365, 370 n.7 (1960).

108. 29 U.S.C. $\S \S 141-68$ (1958). 
By 1940 the attitude and personnel of the Supreme Court also had undergone a change, a fact reflected in the first important labor antitrust decision of the era. Apex Hosiery Co. $v$. Leader ${ }^{109}$ was a suit for damages resulting from a violent "sit-down strike" which not only damaged the plaintiff's plant but also prevented the shipment of finished hosiery in interstate commerce. Apparently there was no concrete evidence that the union's purpose was to prevent Apex products from competing with union-made products and, therefore, Second Coronado ${ }^{110}$ did not apply. Because of this, there was ample precedent, not the least of which was First Coronado, ${ }^{111}$ to hold that such a primary strike for a "local" purpose did not violate the Sherman Act.

The Court, however, speaking through Mr. Justice Stone, was not willing merely to leave it at that and for the first time attempted to formulate and rationalize the broad principles governing labor antitrust litigation. After an examination of the background and purposes of the Sherman Act, it found that union activity was not violative of the antitrust laws unless intended "to restrain commercial competition"112 or "directed at control of the [product] market."113 In the absence of mitigating elaboration, such a test was at best only a partial liberalization of the antitrust restrictions on union activity. Union liability could no longer be premised on notions unrelated to product competition such as the open-ended prima facie tort doctrine and the recurring but absurd theory that the Sherman Act was designed to police interstate traffic. But the test formulated by Mr. Justice Stone, at least in such an unelaborated state, was of equal danger to unions since it would condition the legality of union activities upon their non-interference with product competition and leave unions subject to Second Coronado and the theory underlying it.

But Mr. Justice Stone did not stop there; he proceeded to elaborate the "commercial competition" test. Through an unsuccessful mixture of precedent and "considered" dicta, he attempted to describe to the bar and subordinate bench what kinds of union activity would violate the Sherman Act in the future. And in the process of elaborating the standard, he abandoned it. The per se rule against secondary boycotts apparently was to be retained because, according to Stone, that kind of restraint curtailed the free market and "was aimed at suppression of competition with union made goods. . ."114 If he meant to adopt the per se rule, however, he misapplied his own formulation since, as stated earlier, not all secondary boycotts are intended to repress competition. ${ }^{115}$

109. Apex Hosiery Co. v. Leader, 310 U.S. 469 (1940).

110. Coronado Coal Co. v. UMW, 268 U.S. 295 (1925).

111. UMWW v. Coronado Coal Co., 259 U.S. 344 (1922).

112. 310 U.S. at 497.

113. Id. at 506 .

114. Id. at 507. It is by no means patently clear that the per se rule was to be retained since one rationalization the opinion used to support it, i.e., that secondary activity suppressed competition with union-made goods, was contradicted by an important dictum. See note 117 infra and accompanying text.

115. Sce note 96 supra and accompanying text. 
Second Coronado was also cited, quoted, and ostensibly approved. ${ }^{116}$ Nevertheless, in a dictum which was surely deliberate, the Court said, or rather asserted:

Since, in order to render a labor combination effective it must eliminate the competition from non-union made goods ... an elimination of price competition based on differences in labor standards is the objective of any national labor organization. But this effect on competition has not been considered to be the kind of curtailment of price competition prohibited by the Sherman Act. ${ }^{117}$

This statement, more than any other, has led commentators to believe Apex was an attempt at liberalization of the Sherman Act's restrictions on union activity. But, castally dropped in the midst of everything else in the opinion, it reduced the general formulation established by the opinion to a shambles. For one thing, it added a very important, and largely undefined, "but not always" to Stone's prior statement that union activities intended "to restrain commercial competition" violate the Sherman Act. For another, it seemed a mortal blow to Second Coronado and even cast doubt upon the Court's reasoning as to the illegality of secondary boycotts.

But whatever the fate of Second Coronado, Mr. Justice Stone left no doubt as to the continued vitality of Brims as precedent, for suddenly it was authoritatively labeled as "a case of a labor organization being used by combinations of those engaged in an industry as the means or instrument for suppressing competition or fixing prices."118 Until then, of course, the activity in Brims had been thought to be illegal because it seemed tainted with a secondary coloring and surely involved the very purpose outlawed by Second Coronado.110 Since that purpose was now necessary "to render a labor combination effective," was "the objective of any national labor organization," and was not "considered to be the kind of curtailment ... prohibited by the Sherman Act," the Court had to give Brims a refinishing. But the characterization applied is, as a complete statement of the rule of the case, factually misleading ${ }^{120}$ and

116. 310 U.S. at 511-12.

117. Id. at 503-04.

118. Id. at 501. In his dissent in Bedford Cut Stone Co. v. Journeymen Stone Cutters' Ass'n, 274 U.S. 37 (1927), Mr. Justice Brandeis had sought to distinguish the Brims decision on the grounds it involved a "combination" of employers and a union for a "purpose ... not primarily to further the interests of the union carpenters." Id. at 64 (dissenting opinion).

119. There is certainly nothing in the opinion in Brims, 272 U.S. 549 (1926), or in that disposing of a subsequent case involving similar facts, Local 167, Int'l Bhd. of Teamsters v. United States, 291 U.S. 293 (1934), indicating they represent a line of cases independent of the secondary boycott and Second Coronado decisions. Nor did a leading commentator of the era view Brims as something special. BERMAN, LABOR AND THE SHERMAN ACT 258-59 (1930).

120. The facts in Brims, as stated in the unanimous opinion, 272 U.S. 549 , at 552 (1926), were that unionized employers were hampered by competition from non-union firms "which sold their product in the Chicago market cheaper than local manufacturers who employed union labor could afford to do." Mr. Justice Stone's statement in Apex is misleading in two respects. First, it fails to state what competition was being suppressed, 
legally meaningless, ${ }^{121}$ since it is perfectly clear that the union in Brims was doing what it had to do to protect its own organization and wage scale. After all, the facts in Second Coronado indicated perfectly clearly that the organized operators had let it be known that continued recognition of the union and maintenance of the existing wage scale depended upon suppression of nonunion competition. ${ }^{122}$ The intent and motive of the unions in both cases were identical, the only difference being the means employed. ${ }^{123}$ Second Coronado, therefore, can easily be viewed as a case in which a union was the "means" for suppressing competition. This is not an historical footnote; it is one source of the Court's problems today. ${ }^{124}$

After all this, the Court had no trouble finding the Apex strike legal under the antitrust laws. Surprisingly enough, three justices, in an opinion by Chief Justice Hughes, dissented from this result. ${ }^{125}$ They believed "a deliberate prevention of the shipment of finished goods to customers outside the state"126 violated the Sherman Act. Cases such as First Coronado were easily distinguishable to them since they did not involve finished products. The dissent, written in the face of the Norris-LaGuardia and Wagner Acts, is a striking example of just how free-wheeling judges can be with labor cases under the antitrust laws-assuming, of course, that they are at all applicable-and how much union activity, in the words of Chief Justice Hughes, "falls directly within the language of the Sherman Act in its natural import. . .."127

Apart from obscurity created by the attempt to overrule cases without saying so, the line drawn by the Court distinguishing the legal from the illegal was an invitation to wholesale unprincipled judgments. ${ }^{128} \mathrm{Mr}$. Justice Stone's

i.e., non-union competition based on low wage scales. Second, by using the word "means," it implies the union's conduct was not related to collective bargaining when exclusion of the non-union products was actually essential to maintenance of the union scale.

121. "Meaningless" unless carried to the logical conclusion that elimination of nonunion competition which, because of low labor costs, undersells unionized employers is illegal.

122. 268 U.S. at 306-08.

123. Of course, the cases can be "distinguished" on this basis. But that would mean that while the union in Brims was prohibited from eliminating non-union competition through hot cargo clauses, it could legally (under the Sherman Act) destroy the nonunion facilities (as in Second Coronado) or shut them down through organizational picketing, etc. Even if this "distinction" was thought to be satisfactory, it is certainly not principled.

124. See notes 154-58 infra and accompanying text.

125. Apex Hosiery Co. v. Leader, 310 U.S. 469, 514 (dissenting opinion).

126. Id. at 514 (dissenting opinion).

127. Id. at 517 (dissenting opinion).

128. One fascinating, and frightening, aspect of the decision is the emphasis placed on the fact that the strike had no effect on the price of hosiery. 310 U.S. at 501. At another point, Mr. Justice Stone implies that union activities "so widespread as substantially to affect [the market] ..." are illegal. Id. at 506. Whether these statements were deliberately intended to imply that industry-wide strikes are illegal or that the federal courts have power to determine whether prices are too high because of strike-induced shortages is by no means clear, but they certainly add to the confusion. 
test of legality seemed to turn on the distinction between restraints imposed on labor markets and those imposed on product markets. 129 Thus, the Court's intention to bar restraints on "commercial competition" was qualified by the dictum allowing "an elimination of price competition based on differences in labor standards. ..." But this distinction misconceives the basis of union power and the relationship of product competition to collective bargaining. The activities of the Mine Workers are again instructive. The "willing and able" clause ${ }^{130}$ is little more than a preservation of the right to refuse to work. In terms of its intent and ultimate impact, however, it may have a very dramatic effect on the product market. Similarly, the imposition of uniform high wage rates may be a purposeful attempt to drive out small marginal operators, thereby radically changing the nature of competition in the product market. On the other hand, some of the most direct interventions by unions in product markets, such as prohibitions on sales at a price less than labor costs, are most obviously related to control of the labor market, such as the protection of contractually established wage rates. The distinction between product market and labor market restraints, therefore, cannot be soundly made in the context of a system of collective bargaining based on employee organization along product market lines. And, given the fallacy underlying the generalization, Apex was little more than an invitation to continue an unprincipled approach to the problem.

The Court's opinion itself demonstrates this. The prohibition on secondary boycotts was apparently to be maintained. Second Coronado was to be dropped. Brims, in spite of the fact that it was merely "an elimination of price competition based on differences in labor standards . . .," retained vitality probably because the Court desired to ban hot cargo clauses and had vague and misplaced fears that such activities protected employers a little too much. ${ }^{131}$ But none of these rules is based on generalized principles derived from an examination of the labor antitrust problem. Rather, they are the result of largely undefined and misleading notions as to how much "power" unions should have and how far they should be allowed to limit competition. Apex, therefore, was little more than a demonstration of the insuperable difficulties a court faces when it attempts to formulate generalized principles governing labor antitrust litigation. Such principles exist only in such extreme solutions as barring union organization along product market lines or exempting union activities entirely from antitrust liability. The former solution is unthinkable because of section 6 of the Clayton Act, if for no other reason. And the Court has not been able to accept the latter-except temporarily ${ }^{\mathbf{1 3 2}}$-for reasons which are by no means

129. It may well be that the Apex opinion established no standard at all beyond saying "good" union activities are legal and "bad" ones are illegal. But if there was a test, it was the labor-product market distinction.

130. See note 28 supra.

131. "Vague and misplaced" because a hot cargo clause does not protect organized employers any more than the violent destruction of competing non-union firms as in Second Coronado.

132. See notes $139-42$ infra and accompanying text. 
clear. But middle solutions, requiring arbitrary judgments based as much on the political temper of the country as on logic or experience, do not allow for a principled exercise of the judicial function. Apex, therefore, whether or not a liberalization of the antitrust restrictions on union activity, continued to commit judges to making decisions for which they were ill-suited. Given the institutional framework of the new statutes and given further the unfortunate experience of half a century of judicial attempts to make such decisions, this was a fundamental error.

The extended treatment given to Apex may be surprising in light of subsequent decisions which seem implicitly to overrule it. Apex is, however, of abiding importance today to practicing lawyers, commentators, scholars, and judges. For one thing, the theories underlying subsequent decisions, when applied to concrete factual situations, are far less hospitable to union activities than most believe, and Apex, or at least some of its broad language, has achieved renewed vitality in the briefs of union lawyers defending antitrust litigation. ${ }^{133}$ For another, Apex was an attempt by the Supreme Court, having a majority which did not look upon collective bargaining with great disfavor, ${ }^{134}$ to elaborate general principles governing labor antitrust litigation. Apex, in short, was a major effort and the Court had a half century of judicial experience and informed professional commentary to draw upon, not to mention the legislation of the 30's. The Court's product, however, was not encouraging.

But for later developments, the Court might have left things as they stood. Norris-LaGuardia had been interpreted to prevent issuance of injunctions in labor disputes whether or not the union activity involved violated the Sherman Act. ${ }^{135}$ Damage actions had never been particularly satisfactory to employers and were probably rendered even less so by the uncertainties in substantive law left by Apex. ${ }^{136}$ Apex, therefore, might well have remained the law, not because it offered a satisfactory solution, but because the issue itself might have remained relatively dormant, thereby allowing the Court to avoid the inevitable difficulties constant litigation would bring. Such was not to be the case, however, for the Department of Justice had begun a series of criminal prosecutions against unions for alleged antitrust violations. The labor activities sought to be curbed involved "unreasonable restraints" resulting in featherbedding, price-fixing, extortion or disruption of established collective bargaining rela-

133. Milk Wagon Drivers' Union v. Lake Valley Farm Prods., Inc., 311 U.S. 91 (1940).

134. See notes 192-97 infra and accompanying text.

Paradoxically, others who take existing law at what might very loosely be termed its face value, i.e., a labor exemption with a narrow exception for "combination" cases, seem to view Apex wistfully as a commendable decision. See, e.g., Atr'y Gen. Nat'l Comm. ANTITRUST ReP. 296 (1955).

135. The dissent by Chief Justice Hughes, moreover, obviated the necessity of moulding the opinion to satisfy those who were less hospitable to collective bargaining.

136. Comment, Labor Injunctions and Judge-Made Labor Law: The Contemporary Role of Norris-LaGuardia, 70 YALE L.J. 70, 72 (1960). 
tionships. ${ }^{137}$ The common characteristic of all of these was not so much their effect on competition or their impact on the economy as it was the Justice Department's ad hoc judgment as to their undesirability. ${ }^{138}$ This campaign not only prevented the Court from avoiding the issue but also highlighted the difficulties left by Apex.

United States $v$. Hutcheson, ${ }^{130}$ the first prosecution to reach the Supreme Court, involved a jurisdictional dispute and consumer boycott; the Court's holding seemed to exempt unions from all liability under the Sherman Act. The Court reasoned that Norris-LaGuardia was more than a bar to the use of injunctions in labor disputes. Its "underlying aim . . . was to restore the broad purpose which Congress thought it had formulated in the Clayton Act but which was frustrated . ."140 by the Duplex decision. Section 20 of that statute governed, therefore, and, revitalized by Norris-LaGuardia's broad definition of a labor dispute, specifically immunized the acts of the defendants against criminal liability under the antitrust laws by declaring they should not "be considered or held to be violations of any law of the United States." Mr. Justice Frankfurter, speaking for the Court, formulated the rule of the case in the following fashion:

So long as a union acts in its self-interest and does not combine with nonlabor groups [footnote citing United States $v$. Brims], the licit and illicit under section 20 are not to be distinguished by any judgment regarding the wisdom or unwisdom, the rightness or wrongness, the selfishness or unselfishness of the end of which the particular union activities are the means. ${ }^{141}$

In short, union activity in pursuit of economic self-interest is exempt from the antitrust laws.

Except for the oblique reference to Brims, the decision in Hutcheson seems abundantly correct. Adherence to Apex's "commercial competition" test would have compelled the Court to continue to make ad hoc decisions as to which union activities restrained competition "too much" and as to the relative weights to be given to collective bargaining and competition. Such an undertaking would have been even more difficult than previously in light of the new statutes. Norris-LaGuardia, by prohibiting use of injunctions, and the Wagner Act, by creating new substantive law and entrusting principal enforcement responsibilities to an administrative agency, reflected a congressional desire to end judicial policy-making. Hutcheson, moreover, obviated the danger, ever present in the Justice Department's campaign, of conflict between administrative regulation under the NLRA and judicial regulation under the Sherman Act. ${ }^{142}$

137. See Arnold, The Bottlenecks of Business 251-52 (1940).

138. See Shulman, Labor and the Anti-Trust Laws, 34 ILL. L. Rev, 769, 779-84 (1940).

139. 312 U.S. 219 (1941).

140. Id. at $235-36$.

141. Id. at 232.

142. Section 7 of the NLRA, 29 U.S.C. $\$ 157$ (1958), by affirmatively protecting "the right ... to engage in ... concerted activities for the purpose of collective bargaining 
Hutcheson was the right decision, therefore, not because as a matter of national policy unions should be free to pursue their economic self-interest to the limit but because that judgment was left to more appropriate governmental institutions. Hutcheson, however, was not the end of the matter.

\section{Allen-Bradley:}

The "one line which we can draw with assurance that we follow the congressional purpose."

The bare facts of Allen-Bradley Co. v. Local No. 3, IBEW, ${ }^{143}$ are as follows. Local 3 of the IBEW, having jurisdiction only over metropolitan New York City, organized the employees of most of the electrical equipment manufacturers and contractors in the area. Under the collective agreements, the contractors agreed to buy electrical equipment only from manufacturers in contractual relations with Local 3, i.e., those in New York City, while the manufacturers agreed to sell only to those area contractors who employed members of Local 3. The union, through the usual weapons of picketing and boycotts, prevented non-union operations. Sheltered from competition, the manufacturers were able to raise their prices, while the contractors, with the union's blessing and participation, could rig bids. The result was higher wages and shorter hours for Local 3's members, greater profits for the manufacturers and contractors, exclusion for outsiders and monopolistic prices for the public.

The excluded manufacturers then brought an anti-trust action against Local 3. "Quite obviously," said the Court through Mr. Justice Black, "this combination of business men [the New York electrical manufacturers and contractors] has violated ... the Sherman Act, unless its conduct is immunized by the participation of the union."144 The Court noted that Local 3 was acting in its economic self-interest but stated that if business groups were to be allowed to engage in these activities simply because of a union's involvement, the Sherman Act might be little more than "a futile gesture."145 After paying homage to Hutcheson (but also to Brims), it concluded,

There is, however, one line which we can draw with assurance that we follow the congressional purpose. We know that Congress feared the concentrated power of business organizations to dominate markets and prices. It intended to outlaw business monopolies. A business monopoly is no less such because a union participates, and such participation is a violation of the Act. ${ }^{148}$

Unions violate the Sherman Act, therefore, when they "aid non-labor groups to create business monopolies," 147 and "the same labor union activities may or

or other mutual aid or protection," seems quite inconsistent with much of the judge-made law restricting union activities under the Sherman Act.

143. 325 U.S. 797 (1945).

144. Id. at 800 .

145. Id. at 810 .

146. Id. at 811 .

147. $I d$. at 808 . 
may not be in violation of the Sherman Act, dependent upon whether the union acts alone or in combination with business groups."148

The Court further held that the injunctive remedy was available, in spite of Norris-LaGuardia and the fact that the case involved a "labor dispute,"140 to restrain the union from engaging in further anti-competitive activities in "combination" with non-labor groups. ${ }^{150}$ The opinion does not discuss why NorrisLaGuardia is inapplicable in Allen-Bradley situations, although the Court may have believed that such cases are so completely outside the mainstream of union activities that Norris-IaGuardia was never meant to apply, a dubious ruling in light of the Court's admission that a "labor dispute" was involved. To the same effect, it might be said that since cases such as Allen-Bradley fall outside the substantive exemption created by Norris-LaGuardia and recognized by Hutcheson, that statute's anti-injunction provisions do not apply.

An enormous amount of confusion exists as to the impact of Allen-Bradley. Because the opinion acknowledges that the legislation of the 30's was designed in part to nullify the Court's regulation of union activities under the Sherman Act ${ }^{151}$ and because it purports to avoid a ruling which might seriously impair collective bargaining, ${ }^{152}$ a reader is understandably prepared to believe that Allen-Bradley does not, and should not, constitute more than a "minor exception"153 to Hutcheson. The Court's reasoning, however, cannot be easily channeled in that direction.

Take the requirement that unions "combine with employers." One assumption, indulged in by commentators and the Allen-Bradley Court itself, is that there is a class of cases involving such "combinations" which are clearly distinct from the mainstream of union activities and collective bargaining. ${ }^{154}$ United States v. Brims is generally cited as the first example of such a "combination."155 But Brims was a direct descendant of both Second Coronado and the secondary boycott decisions. Heralded by Mr. Justice Stone's remark in Apex and by a Hutcheson dictum ${ }^{156}$ which characterized it as a "combination,"157 Brims was resurrected in Allen-Bradley without comment as to how it is distinguishable from the decisions which sired it. So there never

148. Id. at 810 .

149. Id. at 807 n.12.

150. Id. at 811-13.

151. Id. at 803-05.

152. E.g., "Our problem in this case is therefore a very narrow one. ..." Id. at 801 .

153. Kelley, Should Labor Unions Be Subject to Anti-Trust Lazus? Yes, $36 \mathrm{MICH}$. S. B.J. 24,27 (1957).

154. See note 6 supra. The Allen-Bradley opinion assumes throughout that the distinction between "combining" and "acting alone" is perfectly clear and presumably wellknown.

155. 325 U.S. 797, 807.

156. United States v. Hutcheson, 312 U.S. 219, 232 n.3 (1941).

157. "Combination" was used in Brims merely as a convenient factual reference. Sce 272 U.S. at 551, 552. The Allen-Bradley opinion, however, uses it solely as a legal conclusion. 
has been an explanation of the purpose, meaning or scope of the requirement that unions "combine with employers." Nor is there likely to be one which will satisfy those who desire to read Allen-Bradley as a "minor exception." The goal of unions is to control the behavior of particular employers, and their principal functional significance is in terms of those firms. Under those circumstances, unions "combine with employers" every time there is agreement between them, or at least when no conflict of interest exists. And if the point is not clear enough stated in that fashion, ask how unions "act alone." Of course, such phrases may well be meaningful in terms of other factors, as will be demonstrated later. ${ }^{15 s}$ But these meanings are not readily apparent in the opinion itself.

Another root of confusion is the Court's failure in Allen-Bradley to set out the facts in detail before beginning its legal analysis. Because of this, readers prepared for a carefully considered, narrow exception to Hutcheson easily infer the wrong set of facts from the legal discussion. For instance, Mr. Justice Black's opinion states that unions may not "aid and abet"159 employers who have "complete power to eliminate all competition among themselves and to prevent all competition from others. ..."160 The implication is that somehow the manufacturers were "using" Local 3 and that Local 3's participation, although in its economic self-interest, really came about only because the employers combined "to eliminate all competition. ..."

Mr. Justice Black's opinion does not upset the findings below. It affirms them and implies the reader should refer to them. ${ }^{161}$ And these findings have a different tone, indeed. ${ }^{162}$ According to them, the union was "the actuating party"103 and "brought about"164 the monopoly. When Local 3 organized the manufacturers, they were in a "precarious" financial condition and had only a small part of the New York City trade.185 The improvement of working conditions obviously depended on bettering the competitive position of the manufacturers. Local 3 then used certain "inducements" to get the contractors to agree to buy equipment only from employers of Local 3 members. ${ }^{168}$ One such inducement was a bid-rigging scheme in which profits were in part a percentage of the cost of equipment. ${ }^{167}$ The higher the cost, therefore, the higher the profits and the greater the share for the union.

158. See note 175 infra and accompanying text.

159. 325 U.S. at 801 .

160. Id. at 809.

161. "The facts were sufficiently set out in the opinions below and need not be detailed again." Id. at 798.

162. Allen-Bradley Co. v. Local 3, Int'l Bhd. of Elec. Workers, 41 F. Supp. 727 (S.D.N.Y. 1941).

163. Id. at 750 .

164. Id. at 728 .

165. Id. at 731 .

166. Id. at 743 .

167. Id. at 732-33, 743. The union also required that every employer of Local 3 members join a price-fixing code committee. Ibid. 
Of course, most of the manufacturers and contractors did not resist such a scheme. But this was not only because it was profitable. One finding was that no contractor could do any important electrical work in New York City unless the union agreed. ${ }^{16 s}$ Another was that "the most powerful of the contractors or of the manufacturers was absolutely incapable of successfully contesting any issue with the union."169 The special master was so impressed with the union's ability to get what it wanted that there are two full pages in the West Reporter entitled "Power of Union."170 Apart from whatever profits might have been involved, therefore, the employers never had any real choice in the matter, and the few that resisted simply didn't do important electrical work. Indeed, if ever there was a union capable of "acting alone," it was Local 3.

What then can we make of Allen-Bradley? Some possible theories can be dismissed out of hand. One is that the decision merely bars "sham" arrangements by businessmen seeking to hide behind the skirts of labor's antitrust “immunity." Such a case was United States v. Women's Sportwear Mfr's Ass'n. ${ }^{171}$ There, a trade association of contractors in the garment industry refused to work for jobbers who did not contract to give all their work to available association members in good standing with the ILGWU. But, since the union had no part in the arrangement and since some contractors in good standing with the union were not members of the association, it was clear that the labor provisions of the scheme were a fraud and could not serve to immunize it. This was not true in Allen-Bradley, however. The union there was both the "shield" and the "sword," and no employers were defendants in the case. ${ }^{172}$

Another theory might analyze the facts of Allen-Bradley and find conduct by the employers which goes beyond the demands and needs of the union. ${ }^{173}$ Having found that, the decision could be read to permit passive acquiescence but prohibit an overly active response by employers to union demands for restraints on competition. ${ }^{174}$ This is hardly an intelligible principle, however,

168. Id. at 730. Indeed, Local 3 had "almost the power of life and death" over the employers. $I d$. at 749.

169. Id. at 731 .

170. Id. at 741-43.

171. 336 U.S. 460 (1949).

172. In spite of Mr. Justice Black's assertions as to the power of the employers "to prevent all competition from others ...", 325 U.S. at 809 , it is perfectly obvious that the scheme depended absolutely upon Local 3's initiation and policing. Without Local 3, for instance, no effective sanctions could be imposed on contractors who bought equipment from "outside" manufacturers.

173. One passage of the master's findings might be so read as to one instance of pricefixing. $41 \mathrm{~F}$. Supp. at 742. Generally, however, the heavy hand of Local 3 could be seen behind every anti-competitive device, including the price-fixing. See id. at 732-33.

174. Mr. Justice Black's opinion does not discourage such a reading when it states the hot cargo agreement "was but one element in a far larger program in which contractors and manufacturers united with one another to monopolize all the business in New York City, to bar all other businessmen from that area, and to charge the public prices above a competitive level." 325 U.S. at 809 . None of this is incorrect, of course, but it 
since the less competition there is, the more secure the union will be. And since a court seeking to apply such a rule will eventually have to look to the union's self-interest to determine what was demanded and what was not, it would prohibit little more than would the "sham" theory. In any event, such a test would require that the employers be made defendants, as they were not in AllenBradley.

Indeed, the facts of the case and the absence of employer defendants would seem to bar any reading which limits Allen-Bradley to a theory which prohibits employer conduct but not union activity directed to the same purpose. ${ }^{175}$ Nevertheless, Mr. Justice Black's opinion does lay great stress on the activities of Local 3's employers. What the opinion says is that the character of management's behavior determines the legality of the union activity. Mr. Justice Black begins his opinion by noting, "Quite obviously, this combination of business: men has violated both Sections (1 ) and (2) of the Sherman Act, unless its conduct is immunized by the participation of the union." From there, he proceeds to the conclusion that the Sherman Act will be "little more than a futile gesture" if this activity is allowed and thence to the apparent rule of the caseif management's conduct is such that, viewed apart from the union's role, it violates the Sherman Act, then union participation in the scheme is also illegal. Or, as the Court put it, "A business monopoly is no less such because a union participates, and such participation is a violation of the Act."

There is a superficial plausibility to this test. After all, the employers in Allen-Bradley, regardless of who was "the actuating party," did agree among themselves as to prices and markets, albeit they also agreed with the union. Why should the union's participation immunize the scheme, and, indeed, why should the union itself be immunized once the management violation has been demonstrated? The union's liability will turn not on a judicial judgment as to the desirability of its activities but on established antitrust rules applied to business conduct. ${ }^{176}$ In the words of Mr. Justice Black's celebrated dictum, "the same labor union activities may or may not be in violation of the Sherman Act, dependent upon whether the union acts alone or in combination with business groups."177 This does not mean, of course, there cannot be an AllenBradley violation when only one employer is involved, since a single employer may violate section 2 of the Sherman Act by attempting to monopolize and,

should be read in light of the findings below which the Court implies, by omitting them, are legally irrelevant. These could be summarized in part as: (1) breach of the contractor-manufacturer "unity" was at the price of leaving the industry for lack of a contract with Local 3; (2) other businessmen were barred by Local 3's enforcement of the hot cargo agreements; (3) all contractors who dealt with Local 3 had to comply with the "code arrangement" (price-fixing) "in which the all-powerful business manager of the union participated." 41 F. Supp. at 732.

175. There is no little irony in the fact that for all the Court's finger-shaking at the "business monopoly" in the case, the plaintiffs apparently did not consider Local 3's employers worth suing.

176. See Comment, 70 Yale L.J. 70, 91-92 (1960).

177. 325 U.S. at 810. 
presumably, union participation in the attempt will create liability. ${ }^{178}$ If there had been only one electrical manufacturer in New York City, for instance, the holding in Allen-Bradley should be the same on that aspect of the case. It does mean, however, that if employers do not agree among themselves on the scheme, resist the union demands and acquiesce only under pressure, Allen-Bradley is inapplicable. And, indeed, later cases have tended to turn on the question of whether management jumped at the chance to restrain competition or resisted the union's demands. ${ }^{179}$

Leaving aside for the moment the question whether this test makes any sense -it will be argued later that it does not ${ }^{180}$ - we may examine the extent to which it impairs familiar aspects of collective bargaining. A good starting point is a brief examination of what constitutes a conspiracy under the antitrust laws and the question whether employers must explicitly agree with each other on a restrictive scheme to run afoul of Allen-Bradley. The case law under the Sherman Act demonstrates that surely they do not. In Interstate Circuit Inc. v. United States, ${ }^{181}$ several motion picture distributors made individual but identical agreements, restricting subsequent-run exhibitions, with, and upon the request of, two first-run exhibitors. There was, however, no explicit agreement between the distributors. The Court held, nevertheless, that a conspiracy among the distributors existed because each knew that the participation of the others was contemplated and that "cooperation was essential to successful operation of the plan."182 In short, it was apparent that no distributor could have executed the agreement without believing his competitors would similarly restrict their own freedom of action. Having established that, a conspiracy could be inferred.

The implications of this in the labor context are immediately apparent if one substitutes "union" for the two first-run exhibitors and "employers" for the distributors in Interstate Circuit. It is very common for employers to enter into collective agreements upon the presumption that the same terms will be imposed on competitors. Indeed, that is the whole point of the familiar "mostfavored nation clause."183 But does the Court need to, or should it, go so far as to incorporate so-called notions of "implied conspiracy" into the labor context? Assume that in Allen-Bradley each contractor bargained individually with the union, and each agreed, with or without a "most favored nation clause," to buy electrical goods only from manufacturers in contractual relations with Local 3. Isn't it perfectly clear that no individual contractor could

178. Cf. United States v. Bitz, 282 F.2d 465 (2d Cir. 1960); United States v. Hamilton Glass Co., 155 F. Supp. 878 (N.D. Ill. 1957).

179. See, e.g., Jewel Tea Co., Inc. v. Local 189, Amalgamated Meat Cutters, 52 L.R.R.M. 2729 (N.D. Ill. 1963) ; Adams Dairy Co. v. St. Louis Dairy Co., 260 F.2d 46 (8th Cir. 1958); Philadelphia Record Co. v. Manufacturing Photo-Engravers Ass'n, 155 F.2d 799 (3d Cir. 1946).

180. See notes 198-203 infra and accompanying text.

181. 306 U.S. 208 (1939).

182. Id. at 226.

183. See note 34 supra. 
afford to limit his freedom of action in this way unless his competitors were similarly restricted? Isn't concerted action obviously "essential to successful operation of the plan"? Isn't it clear that if the actual facts of Allen-Bradley constitute a violation, then the hypothetical facts should also? Indeed, a reluctance to go this far stems not from reservations with notions of "implied conspiracy" but from the thrust of Allen-Bradley itself. ${ }^{184}$ After all, "a business monopoly is no less such because a union participates. ..."

Turning from the manner in which Allen-Bradley conspiracies may arise, we must examine substantive aspects of collective bargaining which may fall within the prohibited area established by that decision. In Lewis v. Pennington, ${ }^{185}$ a Tennessee jury rendered a verdict against the UMW upon allegations that the union had conspired with the major coal companies to drive smaller operators out of the industry. ${ }^{186}$ The plaintiff contended that both the union

184. Otherwise, Allen-Bradley is little more than a veiled, ad hoc and legislativelyunauthorized attack on multi-employer bargaining. Cf. NLRB v. Truck Drivers Local 449, 353 U.S. 87 (1957).

185. 1961 Trade Cas. If 70,036 (E.D. Tenn. 1961).

186. There were also allegations that a purposeful attempt had been made by the UMW to put plaintiff out of business through union investments in competing mines. The judge's charge, however, authorized a verdict for plaintiff on the grounds stated in the text. The charge read in part:

It is the contention of Phillips Brothers [plaintiffs] that after World War II the economics of the bituminous coal industry became unstable by reason of the fact that there was more coal being produced than the market required; that before 1950 the major coal producers and the Union agreed that the major problem of the industry was over-production and that the growth of small, independent and nonunion producers was contributing to the problem; that the major companies and the Union disagreed on the solution of the problem immediately following World War II.

That the Union contended that the working time of the employees should be cut and urged a three-day week. That the major coal companies were opposed to the Union's dictating the working time of the men in the industry.

That a marked change occurred in the relations between the Union and the major coal companies in 1950; that the express understanding at the time of the signing of the 1950 Bituminous Coal Wage Agreement was that the ... problem of stabilizing the economics of the industry was to be taken care of by eliminating the smaller and weaker companies in great numbers.

That the conspiracy involved the use of the National Bituminous Coal Wage Agreement and its successive amendments as an instrument in accomplishing the purposes of the conspiracy was furthered by the domination of the Union over the men in the industry and that in 1950 the Welfare Fund was turned over [to] the Union's control, and that rather than oppose the Union's efforts to evade the TaftHartley Act as they had before, the major companies fostered the Union's domination of the men of the industry so that the terms of the National Bituminous Coal Wage Agreement could be imposed upon the small mines; that by successive amendments to the Uniform National Bituminous Coal Wage Agreement's terms and wage scale, the Welfare Fund payments per ton were raised to exceedingly high levels; that the mechanization program of the major coal companies was to go ahead rapidly and that the successive increases in wage scale and Welfare Fund Payments 
and the large companies had agreed, before 1950, that the major problem of the industry was overcapacity resulting from the large number of mines. At the time, UMW policy was to limit production by cutting the working time of

were designed and tailored to meet the abilities of the major coal companies to mechanize and not have their profits affected by the increasing labor costs in the successive amendments; that the successive amendments to the labor contract were made after careful consideration of the abilities of the major coal companies to make the increases without affecting their profits; that the Union had no concern as to whether the weaker companies could pay; that the Union displayed its knowledge that the weaker companies could not pay and that they would fall by the wayside by reason of the increased terms; that the Union favored the taking over of the industry by the large combines of coal producers and that the Union worked toward this end; that the campaign to impose the wage contracts upon the smaller companies was intense after $1950 \ldots$ that the finances of the Union and the finances of the major coal companies have been used to further the drive to bring all production under the contract; that one or more major coal companies has assisted in crushing the oppositon of the principal Union competitor of the UMIW in the bituminous coal labor fields; that the result of this conspiracy and these activities has been that large numbers of small companies have been driven out of employment: that to accelerate the demise of the smaller companies devices were inserted into later amendments of the National Bituminous Coal Wage Agreement to further restrain their trade; that companies which could not afford to pay the wage scale were barred from operating on the lands of signatories to the contract; that the small companies were prohibited from selling coal to the signatories to the contract, including the major companies which supplied coal to the large market under large contracts.

That in 1955, the conspirators manifested their intent to take over the TVA market by working with the Secretary of Labor to obtain a determination of a minimum wage in the bituminous coal industry, under the Walsh-Healey Act; that the purpose was to drive out of the Government market, particularly the TVA market, the small coal producers; that this determination imposed a wage rate upon a producer of coal supplying coal to a Government market twice as high as the wage rate determined by the Secretary of Labor in any other industry; that this determination of a minimum wage effectively barred Phillips Brothers from participating in the term market of the TVA because they could not pay the kind of wages set forth in that determination; that because contracts for less than $\$ 10,000.00$ were exempted from the minimum wage determination, Phillips Brothers was able to ship coal to TVA spot orders; that the conspirators set about to eliminate or drastically reduce the spot market of TVA; that when this effort failed to bring results, the conspirators adopted the practice of predatory pricing to drive the spat coal market price down to a price which a small producer could not meet at a profit . . . that large amounts of tonnage were dumped upon the spot coal market of TVA at constantly reduced prices; that the spot coal price was beaten down to such extent that Phillips Brothers suffered large losses in trying to retain their position in that market and finally had to abandon their sale of coal to that market and it became necessary for them to abandon the partnership business.

That the small companies who survived the onslaughts of the conspiracy have been killed off by such lawsuits as this brought by the Trustees of the Welfare Fund; that prior to 1958 some three or four cases were brought by the Trustees against some of the larger producers in the area; that cases against the smaller producers were commenced in 1958 and that some forty-one of these cases have been 
employees, but the major firms resisted this. In 1950, however, a solution was reached and effectuated by execution of the National Bituminous Coal Wage Agreement. The plan adopted was to stabilize the industry through uniform imposition of high wage and welfare levels which were tailored to fit the ability of the large operators to mechanize. The small firms, being unable to automate, would thereby bear a larger relative burden of the increased costs than their big competitors and would ultimately go out of business. Part of this scheme, it was alleged, was the agreement of the major companies to buy coal from other firms only when mined under the terms of the National Agreement and not to allow any firm to work on their lands unless it was in compliance with the agreement.

The kinds of evidence supporting the jury verdict in Pennington dramatize the broad impact of the "business monopoly" test on collective bargaining. First, there has been substantial labor peace in the industry since execution of the National Agreement in 1950 when labor and management were under an eighty day Taft-Hartley "emergency dispute" injunction. Wages and welfare payments have steadily increased since then as a result of peaceful collective bargaining. The union, through various devices, has attempted to impose the terms of the various agreements uniformly throughout the industry and has sought enforcement of its contracts in the courts. The union has encouraged mechanization in order to increase employee productivity. Is this conduct a radical departure from the mainstream of collective bargaining?

But it is also clear that if Allen-Bradley means what it says and if the plaintiff's allegations in Pennington were proved, then the UMW has violated the Sherman Act. Whatever may be required to fulfill Allen-Bradley's "combination" element is certainly present. The operators of the larger mines agreed among themselves to accept the higher wage and welfare demands of the

brought and are presently pending against the small companies of the area in the State of Tennessee since January 1, 1958.

That the UMW, in carrying on the foregoing activities pursuant to its understanding and agreement with the major coal companies was not acting alone to further its own interests, as an organization of wage earners, but was aiding, abetting and cooperating with businessmen in an effort to restrain trade of small companies and to monopolize the industry for the major coal companies; that the conspiracy involved boycotts and the purpose to stabilize the prices of coal in the industry; that the practices used pursuant to the conspiracy, particularly the imposition of the constantly increasing terms of the National Bituminous Coal Wage Agreement upon the small coal companies such as Phillips Brothers and the pricecutting practices of the conspirators on the markets supplied by Phillips Brothers were unreasonable.

That a central part of the agreement, along the alleged conspirators was that the terms of the National Bituminous Coal Wage Agreement would be imposed upon the smaller and financially weaker coal companies with the knowledge and intent that these companies in large numbers would go out of business because they could not pay the increasingly higher prices and welfare royalties which were designed to meet the abilities of the large combines to pay as the mechanization programs of the large companies progressed. ...

1961 Trade Cas. $\llbracket 70,036$, pp. 78126-28. 
UMW. Having the assurance of the UMW that these would be uniformly imposed throughout the industry, they had little to gain from resistance-and everything to gain from agreement-since the demands were in part intended to wipe out their smaller competitors. Agreement by the large operators, moreover, had a coercive effect on the small mine owners, since the latter were then faced with a choice between possible financial disaster through compliance with the high terms of the National Agreement, and a strike while their larger competitors continued to operate. Nor is there a significant difference between the agreement of Local 3's employers to the "hot cargo" clauses-the foundation of the Allen-Bradley arrangement-and the agreement of larger coal operators to the exclusionary wage and welfare levels in Pennington. In both, the employers agreed to contract terms which, when uniformly imposed, would serve to eliminate competitors. And it is a fair inference that the incentive in each case was a combination of union power and ultimate benefit to complying firms. On principle the cases are indistinguishable.

The only articulated exception to Allen-Bradley involves the so-called independent contractor or entrepreneur, typically an individual who, while "independent," supplies little other than his own personal labor. Where he is in "job or wage competition" or has some other as yet undefined "economic interrelationship"187 with unionized employees, a union is apparently free to use economic force to govern the terms on which he is hired and to take other steps to prevent him from undermining union organization and standards by cut-rate operations. ${ }^{188}$ The ramifications of this exception are by no means clear ${ }^{189}$ and, in some ways, it may well be inconsistent with Allen-Bradley ${ }^{100}$ Nevertheless, for purposes of this commentary, it is sufficient to note its existence and suggest that legislative guidance is as necessary here as it is on the central problem of Allen-Bradley itself. ${ }^{101}$

187. See Los Angeles Meat \& Provision Drivers Union v. United States, 371 U.S. 94 (1962).

188. See Milk Wagon Drivers v. Lake Valley Farm Products, 311 U.S. 91 (1940); Local 24, Teamsters Union v. Oliver, 358 U.S. 283 (1959).

189. It is noteworthy, for instance, that an independent contractor case in which an anti-trust violation was admitted drew forth three opinions in the Supreme Court. Los Angeles Meat \& Provision Drivers Union v. United States, 371 U.S. 94 (1962).

190. If one firm has union members as regular employees while a competitor hires independent contractors for the same kind of work, the unionized employer has a large interest in seeing the union regulate the terms under which the contractors are hired.

191. Another line of cases involves "employers" who have organized into a union which may or may not also have employees as members. When employee participation is minimal, liability is premised on the lack of a "labor dispute" under Norris-LaGuardia. E.g., Columbia River Packers Ass'n v. Hinton, 315 U.S. 143 (1942). Where the union is comprised principally of employees along with some employers, Allen-Bradlcy's "combination" theory is applicable. See Hawaiian Tuna Packers v. International Longshoremen's Union, 72 F. Supp. 562 (D. Hawaii, 1947).

Particularly difficult anti-trust problems can arise in the fishing industry, as, for instance, when employee wages are a percentage of the price received for the fish. See McHugh v. United States, 230 F.2d 252 (1st Cir. 1956). 
The principle or theory upon which Allen-Bradley rests, therefore, is by no means a "minor exception." It endangers many long standing structures and practices of collective bargaining. Union control of the jobber-contractor relationship in the garment industry, for instance, is almost surely illegal ${ }^{192}$ - a dictum in Women's Sportswear states so flatly ${ }^{193}$ _unless the Court is willing to apply the "independent contractor" exception rather freely. ${ }^{194}$ Prohibition in turn might well destroy collective bargaining in that highly competitive industry. ${ }^{105}$ Nor is Pennington a unique case because it involved "traditional" subjects of collective bargaining. Three Courts of Appeals have sustained on the law, although not always on the facts, antitrust challenges to union demands over either wages or hours. ${ }^{190}$ Indeed, any demand for higher wages will have an uneven impact on competitors with disparate positions of strength in the product market or with differing methods of operation. This in turn will lead to differing responses by the employers to the union proposals and, if an individual or group of businessmen can demonstrate that the demands were tailored to fit the competitive needs of another, many normal aspects of collective bargaining will be endangered. Behind all this, moreover, is the spectre of enforcement by the labor injunction, so blindly employed by the Court in Allen-Bradley. If Pennington is right-indeed, if Allen-Bradley is right-then federal courts may, in no small number of circumstances, enjoin primary strikes for higher wages at the behest of private parties. It is little wonder, therefore, that union lawyers have turned in desperation to $A$ pex. ${ }^{197}$

But breadth of impact on collective bargaining and conflict with the goals of the NLRA are not all that is wrong with the theory apparently underlying Allen-Bradley. There is a large element of unreality inherent in the test itself. If a union is intent on repressing competition, at least some employers are very likely to be benefited, and a court should not feel very honest about placing great stress on formal demonstrations of resistance which evaporate at the

192. Control of this relationship involves both market-sharing and price-fixing and is patently to the benefit of a substantial number of the contractors. See notes 31 and 36 supra. But see Davis Pleating \& Button Co. v. California Sportswear \& Dress Ass'n, 145 F. Supp. 864 (S.D. Calif. 1956) ; Greenstein v. National Skirt \& Sportswear Ass'n, 178 F. Supp. 681 (S.D.N.Y. 1959).

193. 336 U.S. 460 , at 464.

194. Arguably, the contractors are merely suppliers of labor since the materials are provided by the jobber. The difficulty is that the contractors hire employees and thereby supply more than their personal labor.

195. This fact has had no little effect on the course of decisions. See Greenstein v. National Skirt \& Sportswear Ass'n, 178 F. Supp. 681 (S.D.N.Y. 1959), emphasizing the need of the union to maintain control of the jobber-contractor relationship.

196. Adams Dairy Co. v. St. Louis Dairy Co., 260 F.2d 46 (8th Cir. 1958) (wages) ; Philadelphia Record Co. v. Manufacturing Photo-Engravers Ass'n, 155 F.2d 799 (3d Cir. 1946) (night work) ; Jewel Tea Co. v. Local 189, 274 F.2d 217 (7th Cir .1960) (hours of work).

197. E.g., Main Brief for the UMW, pp. 5, 27, 35-36, 57-58, 61, 68, Lewis v. Pennington, on appeal, No. 14,809, 6th Cir. 
eleventh hour. Indeed, if a union backs a demand for $\mathrm{X}$ wage scale with a strike threat and couples it with an offer to repress competition so the employers will have the ability to pay, what should the employer do? Allen-Bradley says they must resist, even though the union's proposals-since it is at this point "acting alone"-are perfectly legal. All of this, of course, results from the fiction that Congress has expressed a conscious and rational desire to exempt unions (Norris-LaGuardia and NLRA) but prohibit business monopolies (Sherman Act).

This aspect of Allen-Bradley, moreover, abandons an important principle developed under the Sherman Act. This has been denoted by Neale ${ }^{108}$ and Brewster ${ }^{199}$ as the requirement that antitrust law be "fair" or "compliable" even where, on occasion, ostensibly sound considerations relating to economic performance must be sacrificed. Because elaboration of the Sherman Act has been left to the judicial process, the standards developed are not strictly economic but reflect in part the need of the judicial process to rely on generalized principles which avoid resort to arbitrary judgments and give the regulated parties opportunity to comply with the rules of the game. The emphasis on "intent" in many Sherman Act decisions is an example of this. ${ }^{200}$ Another is the difficulties courts find in dealing with price leadership situations or oligopolies, 201 in which there is no ostensible price competition. The parties themselves may not be able both to act rationally and engage in price competition since the price cuts of one will be canceled by price cuts of the others with no one gaining any advantage. To require, as a matter of law, the parties to engage in price competition in this situation, is to require them to act irrationally. In short, it is to establish a rule of law with which the parties cannot comply. But the "one line" the Court drew with such "assurance" in Allen-Bradley does just that by requiring employer resistance to union demands-at the price of a strike, perhaps-when no real conflict of interest exists.

Of course, much of this particular problem can be overstated because in many Allen-Bradley type cases only the union is named as defendant and because the employers involved usually have not been terribly concerned over compliance with the antitrust laws. But it does create a very real problem in bargaining situations. The rational thing for an employer to do, when faced with union demands he cannot meet, is to explain why he cannot agree to them. ${ }^{202}$ And since that reason usually is competition, candid bargaining may

198. See Neale, The Antitrust Laws of the United States of Aarerica 423 (1960).

199. Brewster, Enforceable Competition: Unruly Reason or Reasonablc Rules?, 46 Arr. Econ. Rev. 482 (Supp. 1956).

200. E.g., Atr'y Gen. Nat'l Colar. Antitrust Rep. 55-56 (1955); Neale, The Antitrust Laws of the United States of Aarerica 429-32 (1960).

201. Neale, The Antitrust Laws of the United States of America 442-48 (1960); see Att'y Gen. Nat'l Comm. Antitrust Rep. 36-42 (1955).

202. The NLRA clearly contemplates this bargaining situation and has been interpreted to require employers relying on an inability to pay to produce their records. NLRB v. Truitt Mfg. Co., 351 U.S. 149 (1956). 
well be the road to an Allen-Bradley violation. ${ }^{203}$ Nor is the role of the union under Allen-Bradley realistic. It may legally enforce restrictive schemes on employers ("acting alone"), but if the employer agrees too readily, then the union has become a participant in a "business monopoly" and is in violation of the Sherman Act.

Two criticisms may be leveled at this discussion of Allen-Bradley. The first asks, if the theory underlying Allen-Bradley is so broad, why haven't later cases carried it that far? The short answer is that they largely have. The dictum in Women's Sportswear relating to the garment industry and the cases involving wage and hour demands reflect the direction in which the law is moving. All that is lacking is an abundance of cases, and that will come when the practicing bar rids itself of an obsession with Hutcheson. At the present time, Allen-Bradley is a tool for the lawyer in desperate circumstances who has to think of something. Pennington, for instance, was initially a suit for delinquent payments by the UMW's pension and welfare trustees. Counsel for defendant, having no defenses based on the contract, came up with Allen-Bradley. But $\$ 325,000$ judgments (Pennington) and the injunction are bound eventually to attract more than those lawyers who are forced by circumstances to use their imagination.

The second criticism is that this discussion is superfluous, if not wholly irrelevant, because the Supreme Court is not going to carry Allen-Bradley that far. That, however, is not a criticism; it is the point. The facts in Allen-Bradley showed flagrant abuses. When the international union forwarded a "fair list" of manufacturers who were in contractual relations with the IBEW, Local 3 proceeded to eliminate from the list all those who did not hire its members. ${ }^{204}$ One New York City manufacturer was selling products outside Local 3's jurisdiction at half the price charged locally. ${ }^{205}$ The outside manufacturers whose products were excluded from the New York market by Local 3's ban had to threaten to withdraw all financial support from the World's Fair before their products could be used in the construction of their own exhibits. ${ }^{206}$ Allen-Bradley was probably decided the way it was simply because prices and wages were thought to be too high. ${ }^{207}$ Caught between the urge to do something about such

203. And since candid bargaining is an essential component of the good faith bargaining required by the NLRA, Allen-Bradley conflicts with a keystone provision of the labor laws.

204. 41 F. Supp. at 731-32.

205. Id. at 733 .

206. Id. at 742-43.

207. Paradoxically, on the day the Court handed down the decision in Allen-Bradley, it held that a union might lawfully under the Sherman Act drive a firm out of business by refusing to supply labor because of its belief that a partner in the firm had murdered a union member. Hunt v. Crumboch, 325 U.S. 821 (1945). Arguably, however, the union was not acting in its economic self-interest since the basis of its conduct was personal antagonism, and there is, therefore, no "labor dispute" under Norris-LaGuardia. Cf. Bakery Sales Drivers Union v. Wagshal's Delicatessen, 333 U.S. 437 (1948). Given this, anti-trust standards might well be applied in view of the union's monopoly over labor. 
flagrant conduct and the Hutcheson decision, and operating in an area of great emotional significance to the parties, the Court had to find a label which would ostensibly harmonize the irreconcilable and would not appear to overrule Hutcheson. The Court had to demonstrate, in short, that it would not return to the "old days" but also that it would not tolerate flagrant "monopolization." The "business monopoly" theory seemed the answer, ${ }^{208}$ but the other side of the label doubtless reads "For this case only." When the hard case comes up -whether it be the garment industry, "most favored nation clause," Pennington, or what have you-the "one line" drawn with such "assurance" will be, implicitly at least, abandoned with as much certainty as it was inaugurated. Lip-service, of course, will be paid to Hutcheson and Congress' intent.

What the Court will do in such a case is what it has always done. It will make an unprincipled and largely arbitrary judgment as to the legality of the activities involved. If they are to be illegal, a brief reference to Allen-Bradley will suffice, the less said the better. The Court has already employed that device several times. ${ }^{209}$ Difficulties arise only when legality has to be established. The Court may then do several things. It may emphasize the role of the employers in Allen-Bradley with a corresponding deemphasis in the case before it. This can be done either on the facts (the employers "resisted") or on the law (making Allen-Bradley seem no more of a labor case than Standard Oil of N.J. v. United States). ${ }^{210}$ Or the Court may engage in "balancing" several factors, most of them weightless, such as the needs of collective bargaining against the needs of a competitive economy or the policies of the NLRA against the policies of the Sherman Act. Finally, the Court may discuss and distinguish "traditional" (also "legitimate" and "normal") collective bargaining activities from those which are off-color (though not always legitimate, historical inquiry would reveal them to be traditional and normal). For each of these avenues of escape, moreover, there will be readily available support from the commentators. ${ }^{211}$

There may be yet another route, however, for while Allen-Bradley seems to be picking up some strength, it is also becoming something of an anomaly.

208. Given the premise that it should have proscribed Local 3's boycott, the Court's solution is nothing short of ingenious, for it allowed the Court to write a tantalizingly ambigtuous opinion focused on "business" conduct.

209. United States v. Employing Plasterers Ass'n, 347 U.S. 186, 190 (1954); United States v. Employing Lathers Ass'n, 347 U.S. 198 (1954); United Bhd. of Carpenters v. United States, 330 U.S. 395, 400 (1947).

210. 272 U.S. 1 (1926).

211. E.g., in discussing Apex, the Attorney General's report states,

From this decision there emerges a distinction, deemed essential by this Committee, between union activities aiming, on the one hand, at furthering rightful union abjectives and, on the other, at directly "suppressing [commercial] competition or fixing prices" of commercial products.

Art'y Gen. Nat't Comar. Antitrust Rep. 296 (1955).

See also Bernhardt, The Allen-Bradley Doctrine: An Accommodation of Conflicting Policies, 110 U. PA. L. Rev. 1094 (1962), which supports each of these avenues of escape. 
Since the decision, congressional amendments to the labor laws have done much to limit union power to restrain competition. The prohibition on secondary boycotts $^{212}$ has lessened labor's ability to enforce anti-competitive schemes. The limitations on organizational picketing ${ }^{213}$ and the ban on hot cargo clauses ${ }^{214}$ have deprived unions of important weapons needed for use against non-union competition. Indeed, some of the schemes mentioned, such as the UMW's drive against the small operators, may be endangered by an inability to combat nonunion competition. ${ }^{215}$ It might be argued that cases such as Allen-Bradley are preempted by the new provisions, at least when the principal economic weapons involved are "arguably subject to" the NLRA. ${ }^{216}$ But this would be a dubious holding since it requires a finding of congressional intent, and it is quite apparent that none of the amendments were passed with the specific purpose in mind of protecting competition. ${ }^{217}$ Moreover, since Allen-Bradley is based on the "business monopoly" theory, preemption by the labor laws seems an entirely inappropriate ruling. It should be noted, however, that because these amendments do prohibit many of the weapons of economic force used to enforce anticompetitive schemes, labor antitrust cases in the future may be increasingly concerned with "traditional" aspects of collective bargaining such as wages, hours, and opposition to technological change.

As a practical matter, future elaboration of Allen-Bradley will probably leave us near $A$ pex's labor-product market distinction, which is really not too distant from where the Court stood on the day Loewe v. Lawlor was decided. And all Allen-Bradley will have proved is that the more things the Court changes in the labor antitrust area, the less difference it seems to make.

\section{The Judicial Process and Union Liability Under the Sherman Act}

The judicial record in the labor antitrust area, therefore, is not a happy one. Whether employing the Sherman Act as a vehicle for the wholesale formulation of labor policy or merely as a device for mitigating the anti-competitive effects of collective bargaining, the courts have met with little success. Their record raises the question of the appropriate scope of judicial responsibility in dealing with policies irreconcilable through principled distinctions.

212. 73 Stat. 543 (1959), 29 U.S.C. \$ 158(b) (4) (B) (Supp. IV, 1963).

213. 73 Stat. 544 (1959), 29 U.S.C. $\$ 158$ (b) (7) (Supp. IV, 1963).

214. 73 Stat. 543 (1959), 29 U.S.C. \$ 158(e) (Supp. IV, 1963).

215. See Raskin, John L. Lewis and the Mine Workers, Atlantic Monthly, May, 1963, pp. 53, 54, estimating that the volume of non-union coal is now over $25 \%$.

216. San Diego Bldg. Trades Council v. Garmon, 359 U.S. 236, 245 (1959).

217. The Taft-Hartley Congress explicitly abandoned proposals eliminating the Clayton Act's labor exemption when unions engaged in direct market restraints. In doing so, it stated that prohibition of boycotts would deprive unions of an important means of effecting such restraints. It is clear this statement, however, did not imply that the boycott provisions were to be interpreted with a view to protecting competition but merely that their existence made other legislation less necessary. H.R. REP. No. 510, 80th Cong., 1st Sess. 65 (1947). 
Arguably, an unprincipled approach might be acceptable. Collective bargain-, ing, the argument runs, has occasionally led to the flagrant suppression of competition, and something ought to be done about it. Under the present circumstances, only the courts are in a position to do it. Because of political inertia and the complexity of the problem, there has been no legislation on the matter since the obscurity of the Clayton Act, ${ }^{218}$ and there is little hope for any in the near future. Unprincipled decisions, however, can weed out the flagrant cases without substantially impairing collective bargaining, and the situation will not be beyond recall when Congress finally gets around to acting.

But a democratic society must be concerned with a question which is as vital as "what should be done?" That is, who is to do it? Unless we are willing to adopt the position that there are no restraints on judicial power because the law is only what judges say it is, the resolution of any problem must at least take into consideration the functions, responsibilities, and corresponding restraints which characterize the various institutions which make up our system. To attempt solutions of these complex problems through a series of unprincipled decisions is to ignore an important restraint on the judicial process derived from the discipline of the profession of law itself. Fundamental to this discipline is the idea that decisions shall be rendered upon the basis of generalized principle and that like cases shall be treated alike. An ad hoc approach abandons this goal and, by withdrawing judicial action from the scrutiny of informed opinion, tends to open the door to every abuse from bribery to usurpation of power. In short, it abandons the rule of law itself. It is ironic that at a time when many are concerned over ad hoc intervention in labor matters by the executive branch, ${ }^{219}$ others advocate similar action by the far less qualified and less responsible judiciary.

Nor are unprincipled decisions the dependable device some believe. Seventythree years of judicial regulation of union activity under the Sherman Act has shown that if nothing else. In two decades the Supreme Court went from Second Coronado to Apex to Hutcheson to Allen-Bradley, each decision being rendered with increasing certainty. That the vast majority of judges and commentators have not drawn the obvious conclusion is nothing short of remarkable. It is all very well to say the courts won't carry Allen-Bradley very far today (a proposition which, incidentally, may have less validity every year). But the fact remains that if a future court gets the urge to be a little less hospitable to collective bargaining or has a more expansive view of what is flagrant, it will not have to overrule much to do so, no matter which escape route the Court uses in today's hard case. The absence of generalized principle

218. As far as explicit legislation is concerned, this is unquestionably true, but there can be little doubt that one purpose of Norris-LaGuardia was to nullify the judge-made law of the time by depriving the judiciary of its most effective enforcement weapon. See Comment, 70 Y ALE L.J. 70, 71-74 (1950).

219. Wellington, The Future of Collective Bargaining, New Republic, May 21, 1962, p. 12. 
to be derived from past decisions, therefore, can screen radical shifts in the future.

Paradoxically, unprincipled decision-making also limits the Court's flexibility. Having departed in fact from the principal thrust of Hutcheson, the Court today would find it very difficult to use the "self-interest" principle as an escape from the Allen-Bradley trap. In attempting to deal with the flagrant case, the Court's singular accomplishment has been to overrule Hutcheson without providing safeguards against the very real danger that decision was wisely designed to avoid. This much is clear today, for collective bargaining is no longer regarded either by the public or by the nation's political leaders as a sacred institution. Having sown the wind in 1945 with Allen-Bradley, the Court might well reap the whirlwind in 1964 if it attempted to return to $H u t-$ cheson.

We must remember, moreover, that it will often not be the Supreme Court which identifies the flagrant case. To adopt an ad hoc approach is to presume that lower courts, whose use of the injunction is not always subject to effective review, realize that Allen-Bradley doesn't mean what it says and have the same understanding as to what is flagrant and what is not. In the earlier period, when the Supreme Court also attacked the problem on an ad hoc basis, the lower courts literally went wild, ${ }^{220}$ and it is surely an open question as to what would happen today. It is worth noting, moreover, that aside from a return to Hutcheson, the only escape routes available to the Court would not bind lower courts in any meaningful way. And, since the Supreme Court is presumably not prepared to review every labor antitrust case, its failure to establish generalized principles is of crucial importance.

This might be a minor problem if there were some kind of assurance that the issue would remain relatively dormant. But just as the Department of Justice forced $A$ pex's hand and made Hutcheson almost a necessity, an awakening of the bar as to Allen-Bradley's potentialities will inevitably put the Court in a terribly difficult position. This is not an area of the law, after all, in which the parties willingly forego legal advantages, and if Apex showed nothing else, it demonstrated how quickly an unprincipled approach breaks down under the strain of systematic and continuous litigation. Because the problem is so immersed in the emotional hangovers of an earlier day, every new step will tend to force the Court into doctrinal monstrosities over which it may ultimately lose control. Allen-Bradley, of course, is the classic in this respect. It was an attempt to prohibit what the Court thought were flagrant union activities. But its real purpose was obscured by the "business monopoly" test, a standard which not only impairs many aspects of collective bargaining but is also extraordinarily unrealistic.

Because of this, the actual effectiveness of a case-by-case approach in preserving competitive markets is open to very serious question. On the basis of the unemployment figures in coal and the blatant disregard of the union for the

220. See, e.g., the cases cited in note 91 supra. 
interests of a substantial number of its members, a persuasive argument can be made that Pennington is a flagrant case. ${ }^{221}$ But affirmance would allow the lower courts such freedom as to endanger any union attempt to impose uniform working conditions throughout a product market. It appears, therefore, that an unprincipled approach cannot even reach all the flagrant situations, but only those which may be disposed of through superficially innocuous opinions, typically cases openly involving price-fixing or hot cargo clauses. ${ }^{222}$

Nevertheless, doesn't the fact remain that Congress has not acted and is unlikely to act and that this legislative abdication compels the courts to act in appropriate flagrant cases? In spite of the dangers, isn't this judicial activism at a small cost? In a large sense, these questions give the unprincipled approach away, for they expose the factors influencing the Court's determination as to which cases are sufficiently flagrant and which are not. Rather than searching for shared principles or engaging in interstitial legislation, the Court is openly assuming the legislative function presumably abdicated by Congress and, at least in this uncharted area, is attempting to effect a compromise between the political balance and judicial predispositions in each case. And if this much is true, then the whole premise of the position, that Congress has not acted and will not act, is destroyed, for such decisions invite further political inaction. Indeed, it is a safe guess that many proponents of the unprincipled approach don't want legislation for fear that it might go farther than they believe desirable. It is perfectly clear that if the Court abandoned Allen-Bradley and returned to Hutcheson, the chances of legislation would be immeasurably increased; that is precisely why many want the Court to continue approacliing the problem in an unprincipled fashion.

This is not to minimize the political problems involved in enacting labor legislation. They should be emphasized. ${ }^{223}$ But these very difficulties tempt interested parties to avoid serious legislative proposals so long as they believe much of what they want can be achieved in court. And, in the labor antitrust field, legislation will come when the latest unprincipled decision radically departs from the existing political consensus. But this is a terribly inappropriate time for legislation, because many legal problems which the Court should have brought to Congress' attention will have been shoved under the rug of justifying verbiage which accompanies each unprincipled decision. For the Court has

221. See generally the charge to the jury, Lewis v. Pennington, 1961 Trade Cas. If 70,036 (E.D. Tenn. 1961) ; Caldwell \& Graham, The Strange Romancc Bcizocu Joln L. Lewis and Cyrus Eaton, Harper's, Dec., 1961, p. 25.

On the other hand, why shouldn't a union be free to decide that fewer workers with higher wages is better than more workers with lower wages? Or, in any event, should a court decide this is not a "legitimate" labor objective?

222. See, e.g., note 208 supra; and see Local 175, Int'l Bhd. of Elec. Workers v. United States, 219 F.2d 431 (6th Cir. 1955); United States v. Chattanooga Chapter, Nat'l Elec. Contractors Ass'n, 116 F. Supp. 509 (E.D. Tenn. 1953).

223. For a discussion of some of the problems involved in enacting labor legislation, see Brown \& Myers, Historical Evolution, in Public Policy and Colidective BargainING 17-20 (Shister, Aaron \& Summers eds., 1962). 
a very grave and important responsibility in the area, and that is to demonstrate which functions cannot be delegated to it and which techniques of regulation must be employed in legislation directed to the problem. In short, instead of trying to replace Congress, the Court should aid the legislative process by emphasizing and illuminating, rather than obscuring, the legal problems of regulation. That is a responsibility for which the Court, more than any other institution, is suited, but that is the very responsibility it has consistently abdicated.

The best example of the Court's responsibility is illustrated by one principal issue of this section: whether there are standards derived from the Sherman Act which can be employed to regulate union activities, or whether that statute is at all suited to the regulation of collective bargaining. Arbitrary decisions intended only to bar flagrant activities do not rely on any such generalized principles. They do, however, imply that the Sherman Act is suited to such regulation and have done much to keep alive the notion that Congress would be doing something constructive by passing legislation which reads, "The provisions of the antitrust laws are hereby declared applicable to labor organizations." But if the Sherman Act is not suited to the job, then it is the Courtunless its function is to sow confusion-which has abdicated responsibility by not explaining this to Congress decades ago.

The conflict between product competition and collective bargaining based on employee organization along product market lines is plain enough and surely difficult to resolve, albeit that too has been greatly obscured by the Court's approach. The problem is hardly illuminated, for instance, by implying that union-management "combinations" are something distinct from the mainstream of collective bargaining. In terms of the nature of the statutes protecting competition, however, the conflict is impossible to resolve, for the Sherman Act is not at all suited to regulation of collective bargaining. A close student of the antitrust laws has noted:

[T] he courts themselves have always opposed the idea that they should attempt to assess the economic balance of advantage. Economic argument, even of the simplest kind tends to be seen as a slippery slope on which the firm footing needed for a properly justiciable issue cannot be obtained. . . . The strongest judicial tradition in antitrust is that which disclaims any competence in weighing these arguments and denies that any case-by-case assessment of the public interest in the light of thein is or ought to be required by the law.

It is sometimes thought that per se rules give effect to empirical generalizations based on observation of economic effects: that, for example, price-fixing is illegal per se because many instances of the practice have shown over the years that it always (or nearly always) does economic harm. But this is a mistaken view. . . . What is clear and unmistakable in a per se offense is not its economic effect but its restrictive intent.

If per se offenses are those in which the restrictive intent is clear and unmistakable, so the Rule of Reason in modern antitrust is the require- 
ment that by rational inquiry the courts shall establish the true character or intent of what is done when that intent is not at first sight clear. This examination of intent is not an advanced psychological study of the motives of the parties but simply a common-sense inquiry into what they are really doing. ... . ${ }^{224}$ (Emphasis added.)

These standards, however, cannot be applied to collective bargaining or union activity without requiring the courts "to assess the economic balance of advantage." Union price-fixing may be necessary to insure that employers will have sufficient funds to pay the contractually established wage. Control of the jobber-contractor relationship in the garment industry seems necessary to preserve any meaningful form of collective bargaining. Hot cargo clauses, as in Brims and Allen-Bradley, may be necessary to protect union wage scales against products manufactured under "sweat shop" conditions. Manipulation of wage rates so as to drive out small operators in the coal industry is necessary to insure a "living wage" for some rather than a starvation wage for many. So long as collective bargaining is established governmental policy, a finding of restrictive intent does not dispose of any of these cases, for each requires a court to weigh the values of competition against those of collective bargaining and to decide in each case what is in the public interest and what is not. And this in turn requires it to abandon the established and entirely justifiable approach of the courts under the Sherman Act itself. This much was evident at the time of Second Coronado when, to protect product competition, the Court adopted a theory wholly at odds with section 6 of the Clayton Act. The courts, however, overcome by the superficial attractiveness of an unprincipled approach, have never made this crucial point to Congress. Hence, proposals to make the Sherman Act "applicable" to unions persist. Of equal danger, perhaps, is the possibility that Congress will enact as law the "rule" of one of the unprincipled decisions. If Congress, for instance, were to outlaw anti-competitive activities by unions acting "in combination with non-labor groups," this would be as much a failure of the judicial, as of the political, process.

What then, are the alternatives? Presumably, the pervasive regulation establishing, fostering and limiting collective bargaining prevents subordination of the values of that institution to those of the free market and competition. The Court's choice then is between allowing a small amount of flagrant conduct and preventing it through means which pervert the judicial process and delay and misdirect the political process.

The Hutcheson "self-interest" rule should have been maintained on the explicit grounds that the available alternatives required the courts to perform functions for which they, and the Sherman Act, were ill-suited. This is particularly true in light of the very shaky foundation of Loewe v. Lawlor upon which all judicial regulation of labor under the antitrust laws rests. But even if that were firmer ground, the courts nevertheless should have made clear to Congress there is in fact no way for them to "apply" the Sherman Act to

224. Neate, Antitrust laws of the United States of America 427-31 (1960). 
unions so long as collective bargaining is to be an established governmental policy.

We might then be faced, however, with the problem raised by Mr. Justice Black in Allen-Bradley-if businessmen can freely engage in conduct illegal but for union participation, the Sherman Act is little more than a "futile gesture." For after all, if employers are compelled by law to maintain good faith bargaining relationships with majority unions and if those unions are legally free to engage in all activities in pursuit of their economic self-interest-no matter how anti-competitive-we should allow the employers to respond rationally. 225 Business activity "related to"-a phrase quite different from "justified by," with a court determining what is sufficient justification-union demands and collective bargaining probably must also be exempt. This would not, of course, immunize "sham" arrangements such as Women's Sportswear.

The dangers of explicitly permitting such conduct by business and labor should not be minimized, particularly since it might encourage the spread of anti-competitive arrangements by providing a significant antitrust defense. On the other hand, the dangers can be exaggerated. Indeed, if Allen-Bradley were overruled and all the predicted horribles came to pass, there very likely would be legislation. The greater danger is not the lack of legislation but the enactment of bad legislation as a result of the Court's past failure to meet its responsibilities. Moreover, the power of the parties to exclude non-union competition-the foundation of all of these arrangements-is severely limited by the provisions of the NLRA which restrict the use of many of labor's economic weapons. In any event, it cannot be said with any assurance that Allen-Bradley - given the problems of proof and the premise that it is merely a device to prohibit some flagrant behavior-significantly limits the anti-competitive effects of collective bargaining, either through litigation or by deterring the parties from monopoly practices. Unless Allen-Bradley is something other than most people think it is, that decision itself permits a vast amount of business conduct-all but a few flagrant cases in fact-which would otherwise be illegal. The Sherman Act is in fact a "futile gesture" if the Supreme Court will not uphold Pennington, does not unleash competition in the garment industry, and does not outlaw use of the "most favored nation" clause. The "futile gesture" argument, then, is severely weakened by the fact that its proponents themselves are hardly ready to undertake what it purports to require.

It must be acknowledged, however, that the overruling of Allen-Bradley might be at the cost of increased monopolistic practices. The choice before the Court today, therefore, is extremely difficult. On the one hand are the dangers, speculative though they may be, of allowing openly anti-competitive practices. On the other is an ad hoc approach which corrupts the judicial process, delays and misdirects the political process, accomplishes very little in the way of main-

225. The difficulty, of course, is that prohibition of business conduct which does not proscribe union demands directed to the same purpose leaves the employer in an impossible situation. 
taining competitive markets, and which will lead only to more difficult choices in the future. But for this choice among evils, the Court has only itself to thank.

\section{Legislative Remedies}

While the institutional nature of the judicial process suggests that the courts should emphasize and illuminate, rather than attempt to resolve, these legal problems, Congress suffers under no such incapacity, for it can be arbitrary in the very areas where courts must rely on principle and reason. It has been argued here, for instance, that the per se ban on secondary boycotts imposed by the courts under the Sherman Act was wrong for lack of a basis in antitrust principles relating to product market competition. Second Coronado and Brims, on the other hand, were wrong because their principle could not be elaborated in future cases without open and intolerable conflict with Section 6 of the Clayton Act. But neither criticism can be leveled at Sections 8 (b) (4), 8 (b) (7), and 8 (e) of the NLRA, ${ }^{226}$ even though they prohibit many of the same union activities. Other distinctions, as between labor market and product market activities, although clearly unprincipled when employed by courts, may be profitably employed by a legislature. And whereas courts cannot "assess the balance of economic advantage," Congress can and should. The focus of the discussion here, therefore, will be on the scope of the conflict between the national labor and antitrust laws, some of the general considerations which must be taken into account in any legislative attempt to reconcile these policies, and the kinds of legislation which might be employed to this end.

\section{A. The Scope of the Problem}

We may dismiss at the outset notions which continue to regard the Sherman Act as an appropriate vehicle for limiting the power of unions vis-à-vis employers. These distort the purpose of the antitrust laws themselves and clearly ignore the import of the NLRA provisions relating to union unfair labor practices. For similar reasons, the problem is not one of redressing an imbalance in the law which favors unions over employers by eliminating an "exemption" inapplicable to management. That approach, in fact, completely misconceives the problem, for a labor "exemption" may well be of great benefit to those businessmen who deal with unions. Because the Sherman Act is designed to protect and promote "competition in open markets," the sole problem dealt with here is the harmonization of the labor laws with that purpose.

Although collective bargaining is a major force shaping the economy, the nation's labor laws are for the most part unconcerned with purposeful effectuation of, or coördination with, national economic policy. Labor policy has heretofore been regarded as a matter of class war-a struggle for power between competing groups. As a result, the regulations imposed have been largely directed to limiting or increasing the economic power which one side may exercise against the other. And if the labor laws contemplate a need to protect the

226. 73 Stat. 542 (1959), 29 U.S.C. $\$ \S 158($ b) (4); 158(b) (7); and 158(e) (Supp. IV, 1963). 
public from market power created by callective bargaining, they rely upon a conflict of interest and rough balance of power to accomplish it. Because of this, their one concern relevant to national economic policy has been to limit the cost of economic conflict imposed upon the public by strikes, particularly socalled national emergency strikes. ${ }^{227}$

One principal theme of this commentary has been that collective bargaining gives both labor and management power and incentive to restrict product competition and that reliance upon a conflict of interest to prevent this is little short of naive. The labor laws provide neither explicit regulation nor an economic structure purposefully directed to the maintenance of competition, and create a very real conflict with the Sherman Act. The Sherman Act is most effective where the market structure itself would ordinarily lead to a high degree of competition. In highly competitive industries, restraints on competition usually must be fairly elaborate, and collusion and intent can be proven relatively easily. Where the market structure does not make for competition, however, as in the oligopoly situation, the effectiveness of the Sherman Act has been correspondingly reduced. But union-imposed restraints on competition occur most frequently in competitive industries, precisely where the Sherman Act performs at its best.

The labor laws do conflict, therefore, with the Sherman Act, but the extent of conflict should not be overstated. Although the NLRA does not purposefully seek to protect competition from the power and incentives created by collective bargaining, it may do so in fact. Union-imposed restraints on competition depend for their existence upon control of those who compete in particular product markets. The union must be able to compel employers it deals with as a bargaining representative to comply with the scheme and be able to exclude competing non-union products. Any limitation on the economic weapons available to unions, therefore, is likely to restrict labor's power to restrain competition. The prohibition on secondary boycotts, for instance, lessens union ability to cope both with organized and non-union firms threatening to disrupt an anti-competitive arrangement. The Landrum-Griffin amendments, moreover, by prohibiting "hot cargo" clauses and limiting organizational picketing, attack labor's principal weapons against non-union operators. The UMW's campaign against small mines has not been fully successful because of an increase in the number of non-union operators. Similarly, the ban imposed on outside products by Local 3 in Allen-Bradley itself depended upon secondary picketing and hot cargo provisions, both of which are severely limited today. This is not to say, however, there is no longer a problem. For one thing, these provisions are not purposefully directed to the protection of product competition and do not encompass every anti-competitive device available to unions. Area standards picketing, for instance, may not be prohibited by section $8(\mathrm{~b})(7) .{ }^{228}$ For

227. 61 Stat. 155 (1947), 29 U.S.C. $\S \S 176-80$ (1958).

228. Local 107, Int'1 Hod Carriers Union, 138 N.L.R.B. No. 10, 50 L.R.R.M. 1545 (1962). 
another, unions may still organize all competitors by winning the necessary NLRB elections, and the NLRA does not explicitly prohibit price-fixing or restraints imposed through "traditional" demands over wages and hours.

\section{B. General Considerations}

An evaluation of the effect of collective bargaining on product competition in terms of the economist's competitive model is of only limited significance at this point. The Sherman Act itself enforces no such structure on the economy, and it is perfectly obvious that the model is a standard from which reality consistently departs. As a nation we have accepted monopolistic elements in the economy to one degree or another and probably always will. The enforcement of competition has been pursued as a conscious goal of governmental policy only in a very rough manner and has been largely a process of muddling through. ${ }^{229}$

Viewed in this setting, the problem of harmonizing collective bargaining with product competition, while of great importance, is not as critical as theory suggests. Some aspects of the problem, moreover, cannot be resolved without radical changes in non-labor areas of the economy. Where oligopoly exists, whatever anti-competitive effect collective bargaining may have is far more a result of the industrial structure itself than employee organization along product market lines. ${ }^{230}$ There was, for instance, both price leadership and wage leadership in the steel industry long before organization by the Steelworkers. ${ }^{231}$ Finally, the remedies ultimately employed must be justified by more than reference to a model, for whereas the model need serve only as a useful analytical tool, the remedies chosen must function in a very complex world.

Nor is product competition the only value we must seek to further. As developed earlier in this commentary, collective bargaining, by ordering labor markets and preparing the employed worker for participation in the private and public spheres of our democratic society, has gained the consent of employees to the system as a whole. Because it is a system of private ordering, radical tampering must be at the price of restrictions on freedom and will necessarily have unpredictable results.

A proposal which has gained favor with economists and others illustrates many of these problems. ${ }^{232}$ Since collective bargaining's threat to competition stems from employee organization along product market lines, it has been suggested that unions be prohibited from organizing the employees of competing employers and from acting in collusion with one another. In a model, this

229. Some observers have concluded that governmental policy at the state and federal level has done much to create and support monopoly. E.g., Machlup, The Political ECONONY of MoNopoly 181 passim (1952).

230. See Hildebrand, Collective Bargaining and the Antitrust Lazes, in Public Policy and Collective Bargaining 152, 175-76 (Shister, Aaron \& Summers eds., 1962).

231. Seltzer, Pattern Bargaining and the United Steelworkers, 59 J. PoL. Econ. 319, 322-23 (1951).

232. E.g., Lewis, The Labor-Monopoly Problem: A Positive Program, 59 J. PoL. EcoN. 277 (1951). 
provides sufficient countervailing power to eliminate the effects of employer monopsony but protects product competition. Its actual effects, however, are entirely unpredictable. In industries characterized by small firm size, collective bargaining might disappear entirely because of the enormous organizational problems created by the imbalances of the labor market and the high degree of competition. It is fallacious to believe that small, marginal employers have no power vis-à-vis their employees. Their very weakness in the product market gives them compelling incentive to resist all union demands in the absence of assurance that their competitors will be similarly affected. The employees involved, on the other hand, have few effective weapons at their disposal, for even the NLRA prohibitions on the use of economic force by employers are of questionable value in dealing with a multitude of small firms in the absence of systematic enforcement attempts by a national union. ${ }^{233}$ The proposal, moreover, would have an equally destructive impact on those industries, such as construction, in which the employees work for a number of different employers each year. In oligopolistic structures, on the other hand, in which uniformity may be compelled by the very nature of the market, it might have no effect whatsoever. ${ }^{234}$ In the middle range of industries, any number of things might happen. Fragmentation might render some local unions powerless while others, freed from the stabilizing influence of a staff of experts, would become completely irrational-and hostile.

This proposal, therefore, has a uniform and predictable impact only in the model. One actual result might well be an increase in the tempo of industrial conflict, with all the attendant dangers to economic and political stability. Another possible effect, which cannot be discounted, is that in those industries in which fragmentation substantially contributed to the preservation of competitive markets, it would destroy collective bargaining entirely. And if the proponents of this proposal are serious about the matter, surely some consideration must be given to what should replace collective bargaining in those industries -apart from chaos-and what the likely political impact will be. For, after all, if collective bargaining is of any value, it may be more important to have it in the highly competitive industries than in the oligopolies. One solution mitigating these harsh results would be to exempt unions in highly competitive industries from the law. But if that is to be the case, the beneficial effects of fragmentation on competition have been grossly overstated, for the exemption would apply where collective bargaining's anti-competitive effects are greatest. There would then be a very real question as to whether the proposal is worth the trouble. Another solution would be direct governmental regulation of the employment relationship extending not only to wages but also to discharges, seniority and the like. This solution might have substantial anti-competitive effects, particularly since considerations relating to enforcement-as in the gar-

233. The delay involved in litigation is alone a great deterrent to effective enforcement through individual complaints.

234. See note $\mathbf{2 3 0}$ supra. 
ment industry, for instance-might well compel establishment of the same arrangements as had been achieved through collective bargaining. ${ }^{235}$ And such regulation would result in the accretion of governmental power at the expense of private parties.

The foregoing suggests a high degree of caution in approaching the problem. What should be emphasized is the need to work within the existing framework of the laws regulating collective bargaining, for there are no final solutions which are neither intolerably unpredictable nor too costly in terms of other goals. Any change will be at social, political and economic costs which cannot be foretold with certainty, and only by moving slowly and experimenting within the existing legal framework can the dangers be minimized.

All that will be attempted here is to suggest possible directions legislation might take and techniques it might employ. It must be acknowledged that each suggestion will be open to the criticism on the one hand that it does not fully protect product competition and on the other that it impairs some aspects of collective bargaining. But only proposals subject to both criticisms can in fact move toward harmonization of the competing policies without fully sacrificing either.

All proposals, save one, will be for amendments to the NLRA rather than the Sherman Act. The antitrust laws rely heavily upon judicially established principle while the proposed legislation has a completely different character and is designed to mesh with or modify existing NLRA regulation. Legality under the proposed amendments, moreover, might often turn on distinctions with which the NLRB is far more familiar than the courts. And, finally, administrative machinery for use of the injunction, which already exists in the NLRB, ${ }^{236}$ avoids some of the dangers inherent in making that remedy available to private parties.

\section{Legislation}

To facilitate a particularized legislative and judicial approach to the problem of union activity in conflict with norms of competition, the statute must first exempt unions entirely from Sherman Act liability for conduct in pursuit of economic self-interest. Correspondingly, employers should be allowed to defend antitrust actions on the basis that the conduct complained of was imposed upon them by union demands. But this defense ought not to be allowed where the union activities relied on are in violation of the NLRA, as amended. And, to encourage employers to 'challenge questionable union activity before the Board, courts in antitrust actions ought to resolve uncertain cases against availability of the defense-that is, to find that the particular union activity does

235. The large number of tiny contractors in the industry would probably compel governmental regulation to operate principally through the jobbers.

Another danger is that the government might be so sensitive to the demands of labor in particular industries that the result of state intervention will be less competitive than existed under collective bargaining.

236. 61 Stat. 149 (1947), 29 U.S.C. $\$ \$ 160(j), 160(1)$ (1958). 
violate the NLRA for Sherman Act purposes-when such challenges are not made. For if challenges are made, problems of conflict between the NLRB and the courts will be minimized, through initial administrative determinations, and self-enforcement of antitrust goals obtained through the Board's use of injunctive remedies against particular union activities legislatively found to be anti-competitive.

Prohibition of "most favored nation" and related clauses seems a sound initial step toward particularization. These are devices by which employer consent to the terms of a collective agreement is conditioned upon union imposition of identical terms on competitors or by which the union binds itself contractually to impose such terms on others; they assure employers that there will be concerted action as to all matters covered by the collective agreement and lessen the conflict of interest between labor and management. They can serve, after all, as more than an agreement between a union and an employer, for they may also be a signal to competing employers as to what is intended and as to the security arrangements contemplated. This proposal does, of course, have drawbacks. In some industries, where union organization is virtually complete and its power reliable, such a prohibition would have little effect. And where it did have an effect, the result might be to diminish the stability of bargaining relationships and to increase the number of strikes. This, however, is the likely outcome of any device intended to promote product competition and while it might be minimized, it probably cannot be avoided. "Most favored nation" clauses are not essential to collective bargaining and might well be prohibited without catastrophic results.

Whatever anti-competitive effects "most favored nation" clauses may have flow more freely from multi-employer bargaining encompassing the product market. And this institution is far more important to our present system of collective bargaining than such contractual clauses. But even here there is room for maneuver which, while it does not allow for complete solutions, stops short of disrupting entire bargaining structures. The NLRA can explicitly provide that the election of bargaining representatives be on an employer by employer basis ; in short, the Board would not be permitted to direct an election in a unit larger than one firm. It could further provide that any single employer be allowed to withdraw at will from an employer association and not be bound by any agreement subsequently executed by the employer group and the union. And if further and more radical changes were thought desirable, the NLRA might explicitly allow any employer subject to an agreement reached through multi-employer bargaining to abandon the agreement upon notice after a stated term. This would not, of course, prohibit such agreements but merely allow any party to withdraw and engage in further bargaining. All of these proposals would tend to lessen the centralizing and anti-competitive effects of multiemployer bargaining without completely disrupting that institution.

Other legislation might be directed to prohibiting unions and employers from executing certain agreements and from engaging in certain conduct. Fixing the 
price of the ultimate product should be at the top of this list. The dangers of allowing such conduct surely outweigh the justifications in most industries. Results similar to price-fixing, of course, might be achieved through uniform wage scales and could not be barred without substantial impairment of collective bargaining. But such results are difficult to achieve where the operations of the competing employers are dissimilar, and such conduct would be hampered by the proposals relating to "most favored nation clauses" and multiemployer bargaining. The "hot cargo" provisions of Section $8(\mathrm{e})$ might also be strengthened so as to bar all restrictions on the employer's right to engage in business relations with others, with only a very narrow exception for limitations on the right to subcontract work out. Finally, the law might move into the area of "traditional" demands of the labor market and prohibit union-imposed restrictions on the volume of production and the method of operations. ${ }^{237}$ An exception where safety or like matters are allegedly involved could be included, its applicability in particular cases being left to determination by an arbitrator appointed by the Board.

Congress might, moreover, further limit the use of labor's economic weapons. Consumer picketing of retail stores might be barred. All forms of organizational and area standards picketing could be completely prohibited. This, of course, would leave unions virtually powerless to combat non-union competition with economic force. ${ }^{238}$ But the employees of each employer would still be free under the Act to vote in a union, and, in any event, it is not terribly easy to justify organization achieved through economic coercion which effectively deprives employees of their freedom of choice. If it were found that non-union product competition prevented a substantial number of employees in an industry from engaging in meaningful collective bargaining, moreover, judicious and limited use of minimum wage laws might alleviate the situation. ${ }^{230}$

An "independent contractor" exception to the new provisions might be enacted allowing unions to engage in many otherwise illegal activities in particular circumstances. It might be limited to situations in which employees were in actual competition over particular work for particular employers or broadened to allow the use of economic force where the competition was at the product market level within a narrowly defined geographic area. ${ }^{240}$ This might

237. Where the level of wages itself limits production because of cost considerations, very little can be done without substantial impairment of collective bargaining. The law might, however, with less drastic effects, prohibit "discriminatory" wage levels which effectively penalize the use of labor-saving devices. For examples of such "discrimination" against automation, see generally Haber \& Levinson, Labor Relations and Productivity in the Building Trades (1956).

238. Appropriate protection might, if desired, be provided where the non-union workers are strikebreakers.

239. This is a dangerous approach, for there is no clear distinction between use of minimum wage laws as an aid to collective bargaining and as a substitute for it.

240. The first situation involves employers who hire both unionized employees and independent contractors for virtually identical work. Under those circumstances, each employer is tempted to use contractors rather than employees if the former are engaging in 
also be drafted to allow continuance of union control of the jobber-contractor relationship in the garment industry, for the contractors are principally suppliers of labor.

Some of these proposals are obviously better than others, but their sole purpose is to demonstrate that there is room to maneuver within the existing legal framework. Further analysis would undoubtedly reveal even more leeway. It cannot be overemphasized, however, that no complete solution exists, short of abandoning one or the other policy. On the other hand, it is by no means clear that a complete solution is needed, particularly in light of the unpredictable results and costs to freedom that further regulation of collective bargaining necessarily entails.

cut-rate operations. The second situation occurs when one or more firms hires only unionized employees while competitors use independent contractors exclusively. Under those circumstances, the unionized firms suffer competitively unless the union controls the terms on which the contractors are hired. 